\title{
Natural Resources and Fiscal Policy in CEMAC1: The Role of Institutional Quality
}

\author{
Jean Roméo Félix Kouika Bouanza, Ted Cléophane Ngassa \\ Laboratory of Economic and Social Research and Studies (LARES), Faculty of Economics, Marien Ngouabi University, \\ Brazzaville, Republic of Congo \\ Email: romeo.kouika@umng.cg, romeokouika@gmail.com, tedngassa@gmail.com
}

How to cite this paper: Kouika Bouanza, J. R. F., \& Ngassa, T. C. (2021). Natural Resources and Fiscal Policy in CEMAC: The Role of Institutional Quality. Theoretical Economics Letters, 11, 268-301. https://doi.org/10.4236/tel.2021.112020

Received: February 11, 2021

Accepted: April 12, 2021

Published: April 15, 2021

Copyright $\odot 2021$ by author(s) and Scientific Research Publishing Inc. This work is licensed under the Creative Commons Attribution International License (CC BY 4.0).

http://creativecommons.org/licenses/by/4.0/

\begin{abstract}
This article aims to analyze the effects of institutional quality through natural resource rents on the orientation of fiscal policy in the Central African Economic and Monetary Community (CEMAC). The methodology adopted for this purpose is based on panel data (over the 1996-2016 period) and the GMM system estimator. The results show that natural resource rents are a means by which institutional quality affects the orientation of fiscal policy. Indeed, economic and institutional governance complements natural resource rents in the countercyclical orientation of total public spending. Thus, there is an absence of the indirect effects of institutional quality on the orientation of total public revenue behavior. Similarly, during natural resource booms, the orientation of total public spending remains countercyclical. Thus, political and institutional governance reinforces the effects of natural resource booms on the countercyclical orientation of total public spending. With regard to the decline in natural resource rents, total public spending remains countercyclical. Only institutional governance reinforces the effects of the decline in natural resource rents on the countercyclical nature of total public spending. Thus, the procyclical orientation of the behavior of total public revenue remains, regardless of whether there are periods of boom or collapse in natural resource rents. Political governance amplifies the effects of the decline in natural resource rents on the procyclical behavior of total public revenue. These results lead to economic policy implications.
\end{abstract}

\section{Keywords}

Natural Resources, Fiscal Policy, Institutional Quality, Central Africa

\section{Introduction}

Dependence on natural resources can make it difficult to manage fiscal policy, ${ }^{1}$ Central African economic and monetary community (Appendix 1). 
increasing fiscal uncertainty and encouraging suboptimal fiscal policy (Spatafora and Samake, 2012). Indeed, countries that are highly dependent on natural resources, such as CEMAC countries, are vulnerable to major and persistent shocks due to the volatility of commodity prices. Thus, combined with weak institutions, these countries tend to pursue procyclical fiscal policies.

To address this procyclical bias in fiscal policy, resource-rich countries, particularly CEMAC countries, have adopted multiple measures, including institutional reforms. Clearly, trends toward improvements in the procyclicality bias of Sub-Saharan African (SSA) countries appear to be associated with better institutions and the adoption of fiscal rules that promote policy space and credit access (Lledó \& Poplawski-Ribeiro, 2013; Calderon and Nguyen, 2016). As a result, improving the quality of governance is proving to be a means capable of allowing a countercyclical orientation of fiscal policy.

Additionally, it is commonly accepted in the literature that fiscal policies in developing countries are procyclical, while they are less so or are countercyclical in developed countries (Kaminsky et al., 2004; Ilzetski and Vegh, 2008; Jha et al., 2014). Indeed, two (2) main arguments have been proposed to explain this procyclicality of fiscal policies in developing countries. The first argument relates to borrowing constraints (Aizenman et al., 2000; Gavin and Perotti, 1997). Indeed, resource-rich countries face financing constraints when natural resource rents fall and, consequently, fiscal policy is pro-cyclical with respect to natural resources. The second argument relates to institutional quality (Gavin and Perotti, 1997; Lane, 2003; Kaminsky et al., 2004; Talvi and Vegh, 2005; Alesina et al., 2008). According to this argument, the natural resource boom is associated with increased public spending when institutions are inadequate.

With respect to work in developing countries, the procyclical orientation of fiscal policies has been proven much more in relation to GDP (Bova et al., 2016; Calderon and Nguyen, 2016; Lim, 2020) than in relation to commodity prices (Spatafora and Samake, 2012; Cespedes and Velasco, 2014; Bova et al., 2016; da Costa Antonio and Rodriguez-Gil, 2020). Additionally, the evidence that institutions in developing countries can undermine the procyclical orientation of fiscal policy is still insufficient and unclear (El Anshasy \& Bradley, 2012; Koh, 2017; da Costa Antonio and Rodriguez-Gil, 2020; Bergman and Hutchison, 2020). In contrast to the above-mentioned work, we are interested in the trivariate relationship between natural resources, institutional quality and fiscal policy in resource-rich countries in order to complement the existing literature.

Similar to Ouedraogo and Souroueemo (2018), who focused on the concentration of exports, in this research work, the orientation of fiscal policy will be related to the evolution of natural resource rents. Thus, public revenue and expenditure behave procyclically when they have a positive relationship with natural resource rents; that is, they increase as the economy recovers (or when natural resource rents increase), and vice versa.

In CEMAC, on average, the fiscal policy over the 1996-2016 period seems to 
be positively correlated with natural resource rents (WEO, 2018 and WDI, 2018). Additionally, over the same period, the quality of governance appears to be inadequate (WGI, 2018). However, the institutional reforms undertaken since 2000 have contributed to improving institutional quality. Therefore, this work aims to contribute to the debate on whether institutions tend to improve the procyclicality of fiscal policy in resource-rich countries. Thus, the following question is asked: does institutional quality affect the orientation of fiscal policy through natural resource rents? The objective of this work is to analyze the effects of institutional quality through natural resource rents on the orientation of fiscal policy in CEMAC. It also aims to analyze the effects of institutional quality by subsequently considering asymmetric shocks to natural resource rents. This work defends the hypothesis that institutions contribute to correcting the procyclical bias of fiscal policy, particularly in terms of total public spending (El Anshasy and Bradley, 2012; Koh, 2017).

In addition to the introduction and conclusion, this research paper has four sections. The first analyzes the stylized facts in CEMAC. The second provides the essential elements of the review of the existing literature. The third presents the methodological tools, and the fourth is devoted to the results and their discussion.

\section{Trends in Public Expenditures and Natural Resource Rents in CEMAC}

It is clearly observed that, on average, natural resource rents and fiscal policy are positively correlated (Appendix 2). Indeed, in CEMAC, the orientation of fiscal policy behavior depends on natural resource rents. In other words, natural resource rents, on average, seem to dictate the procyclical behavior of fiscal policy in CEMAC. Graph 1 and Graph 2 below provide an understanding of trends in the public spending and natural resource rents in CEMAC.

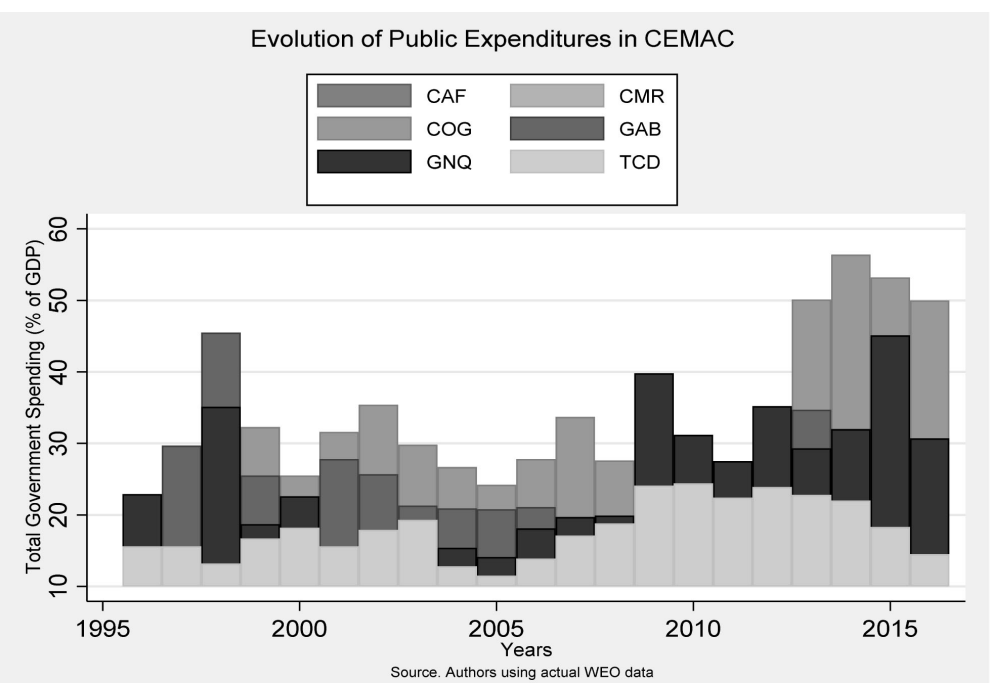

Graph 1. Public expenditure in CEMAC countries. 


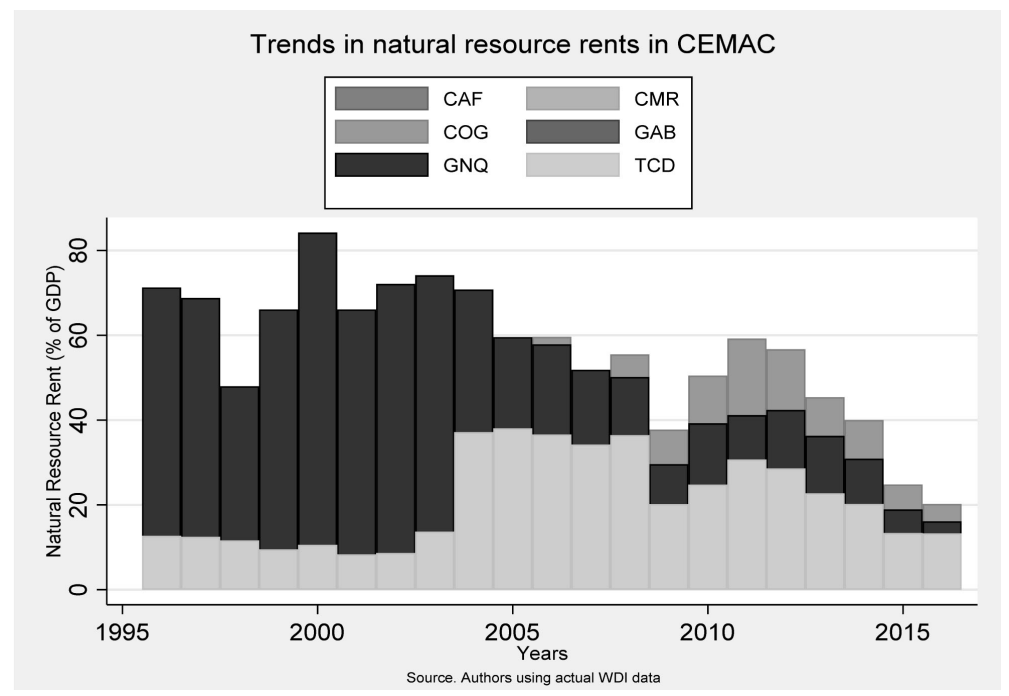

Graph 2. Natural resource rents in CEMAC countries.

It appears that in CEMAC, the size of the state reached more than $50 \%$ of GDP in Congo (in 2014 and 2015). Additionally, in 2013 and 2016, this size reached $50 \%$ of GDP (in Congo). In fact, during these four (4) years, Congo was the largest of the CEMAC countries. Over the entire period under study, the size of the state in Chad, Cameroon and the Central African Republic did not reach $25 \%$ of GDP. In 1997 and 1998, the size of the state in Gabon was $29.7 \%$ and $45.5 \%$ of GDP, respectively. In 2009, 2010, 2011, and 2012, the size of the state in Equatorial Guinea was 33.4\%, 26.6\%, 28.3\%, and 28\% of GDP, respectively. Clearly, among CEMAC countries, Congo, Guinea and Gabon had the highest sizes of state. Additionally, these sizes were above the subregional average $(21.80 \%)$.

It is commonly accepted that countries with a considerable state size are highly dependent on natural resources (Spatafora and Samake, 2012; Cespedes and Velasco, 2014; Bova et al., 2016). As a result, these countries tend to show poor performance in terms of the quality of governance. The graph below provides information on the degree of dependence of CEMAC countries on natural resources.

In the eight years, inclusive, from 1997 to 2004, Equatorial Guinea posted the highest proportions of natural resource rents: $71.25 \%, 68.80 \%, 47.95 \%, 66.09 \%$, $72.13 \%, 74.15 \%, 70.79 \%$ and $59.54 \%$ of GDP. In Congo, natural resource rents amounted to more than 50\% of GDP in 2006, 2008, 2010, 2011 and 2012 (59.60\%, 55.48\%, 50.49\%, 59.20\% and $56.71 \%$ of GDP, respectively). Throughout the period under study, this natural resource rent was below 20\% of GDP in Cameroon and the Central African Republic. In the case of Chad, natural resource rents did not reach $40 \%$ of GDP. In Gabon, however, they exceeded 40\% of GDP in 2000 and 2008. Guinea, Congo, and Gabon have had to achieve levels of natural resource dependence above the subregional average (27.76\%).

CEMAC countries, in this case Guinea and Congo, are highly dependent on natural resources. Thus, it should be noted that in CEMAC countries, the size of 
the state is a function of the degree of dependence on natural resources. Overall, in CEMAC countries, the size of the state increases as the degree of dependence on natural resources increases.

Thus, overall, CEMAC countries are far from performing well in terms of governance quality (Appendix 3). Specifically, disparities are observed in terms of the scores posted between the countries of the zone. Additionally, according to the MO Ibrahim Foundation cited by Ndinga (2018), positive trends have been observed over the last few decades in terms of improving the quality of governance (in Sub-Saharan Africa). On the other hand, the scores posted by CEMAC countries remain lower not only in developed and transition countries but also in South-East Asian and Latin American countries (Kaufmann et al., 2010).

Ultimately, CEMAC depicts a context of high dependence on natural resources, a large state size and a poor quality of governance. Thus, it seems important to analyze the transmission of the effects of this quality of governance on the orientation of fiscal policy via natural resource rents.

\section{Natural Resources, Governance, and Fiscal Policy in the Economic Literature}

According to the existing literature, fiscal policy in developing countries, especially those rich in natural resources, has a procyclical orientation. A number of factors, which can be classified into three categories, explain this procyclical behavior of fiscal policy.

The first category of factors is credit access (by the government and the private sector). In this category, the argument is that during downturns, lenders are wary of the ability of resource-rich developing economies to meet their debt payment obligations. As a result, they reduce their supply of credit (Gavin et al., 1996; Kaminsky et al., 2004). Thus, fiscal authorities have a limited capacity to borrow during the collapse of resource rents, which gives a procyclical orientation to public spending (Gavin and Perotti, 1997). However, development assistance can alleviate internal credit constraints since development assistance is independent of the natural resource rent cycle and makes the budget less sensitive to the availability of credit (Thorton, 2008). Similarly, a strong net foreign exchange reserve position can also reduce the procyclicality of fiscal policy by alleviating the government's credit constraints (Zhou, 2009, 2010).

The second category of factors is the room for maneuvering in fiscal policy. In this category, public sector indebtedness can strongly induce a procyclical stance of fiscal policy. This is illustrated by resource-rich developing countries whose governments have the highest levels of debt relative to other countries. In other words, because of the lower revenues from the collapse of natural resources, these governments will have less room to borrow and, as a result, will find external credit constraints more constraining. They will also have less leeway to adopt countercyclical fiscal policies (Schaechter et al., 2012; Calderon and Nguyen, 2016). Nevertheless, development assistance and positive capital inflows can mod- 
erate these external credit constraints by making resources available for countercyclical fiscal policies (Calderon and Nguyen, 2016).

Finally, the third category of factors is institutional quality. According to this category, during a boom in commodity exports (or an increase in natural resource rents), governments may be led to overspend to distribute the benefits of this shock, with the aim of strengthening their political power (Tornell and Lane, 1999). This is referred to as the voracity effect. Thus, in developing economies (which have large revenues from natural resources) and weak institutions, this effect will result in a procyclical orientation of fiscal policy. Similarly, poor governance, such as corruption, can encourage a procyclical fiscal policy stance when politicians' control systems are imperfect since this allows for greater rentseeking behavior during good times. In other words, when institutions are weak, economic policy and management are poor, and political elites are likely to engage in rent-seeking, while corruption thrives in the bureaucracy and the economy.

In existing empirical work (Bova et al., 2016; Calderon and Nguyen, 2016; Cespedes and Velasco, 2014; Bova et al., 2016; Lim, 2020), for resource-rich developing countries, these results suggest that fiscal policy is procyclical to fluctuations in both output and commodity prices (or natural resource rents). Thus, some authors find that revenues and expenditures are procyclical with respect to the business cycle or GDP (Bova et al., 2016; Calderon and Nguyen, 2016), while other author (Spatafora and Samake, 2012; Cespedes and Velasco, 2014; Bova et al., 2016; da Costa Antonio and Rodriguez-Gil, 2020) find that fiscal policy is procyclical with respect to commodity prices (or natural resource rents). Indeed, this procyclical orientation assumes that revenues and expenditures increase when commodity prices rise, and vice versa (da Costa Antonio and Rodriguez-Gil, 2020).

Moreover, in general, empirical work suggests that the procyclicality bias of fiscal policy has been reduced over the last four or five decades due to improvements in institutional quality (Cespedes and Velasco, 2014; Bova et al., 2016). Similar trends are observed in SSA, although less work has been conducted that focuses on the orientation of fiscal policy relative to GDP (Thorton, 2008; Lledó \& Poplawski-Ribeiro, 2013; Calderon and Nguyen, 2016) rather than commodity prices (or natural resource rents).

For Konuki and Villafuerte (2016), fiscal policy has a procyclical orientation in oil-exporting economies but not in those that export minerals. Similarly, Spatafora and Samake (2012) find that procyclicality in spending is significant only for economies that export the three main traded commodities, including oil. Additionally, da Costa Antonio and Rodriguez-Gil (2020) find that in Angola, revenues and expenditures are generally procyclical with respect to oil (and that revenues are more procyclical). For Ouedraogo and Sourouemo (2018), the concentration of exports in resource-exporting African countries limits the sources of government revenues and, thus, the room for fiscal policy. Consequently, the 
export concentration increases the degree of procyclicality of fiscal policy (and this result is perceived through the behavior of public investment).

As a result, the work finding that institutions can mitigate the procyclical orientation of fiscal policy in resource-rich countries is still limited and ambiguous. According to El Anshasy and Bradley (2012), Koh (2017) and da Costa Antonio and Rodriguez-Gil (2020), the institutional quality in resource-rich countries reduces the procyclical orientation of fiscal policy. However, Lledo et al. (2009) and Konuki and Villafuerte (2016) find evidence that institutional quality does not affect the cyclical behavior of fiscal policy in resource-rich countries.

In sum, the key explanation for the orientation of fiscal policy in resource-rich countries may be offered by the institutional factor. Indeed, the arguments proposed in this regard establish a relationship between natural resource rents, governance and fiscal policy. Therefore, to supplement the existing literature, we are mainly interested in the effects of institutional quality on the orientation of fiscal policy through natural resource rents in CEMAC. More specifically, this research expands the scarce literature on the asymmetry of fiscal policy and helps shed light on the still ambiguous role of institutions in resource-rich economies.

\section{Methodological Tools}

In this section, we present, first, the model specification and estimation procedure (1) and, second, the sources and description of the data (2).

\section{1) Model specification and estimation procedure}

As in Calderon \& Nguyen (2016), Doryñ et al. (2018) and Bouanza et al. (2018), the cyclicality of fiscal policy is generally captured by the state's reaction function in the formulation of its fiscal policy. Under Taylor's (2000) approach, national fiscal policy rules stipulate that net public spending is influenced by the economic cycle or automatic stabilizers $\left(C E_{i t}\right)$ and by discretionary fiscal policy decisions $\left(P B_{i t-1}\right)$. In addition, there is a shock that can influence net public spending in an unpredictable way $\left(\mu_{i t}^{P B}\right)$. Based on the examples provided by Konuki and Villafuerte (2016), Spatafora and Samake (2012), Ouedraogo and Sourouemo (2018) and da Costa Antonio and Rodriguez-Gil (2020), the economic cycle or GDP will be substituted by natural resources ( $\left.T N R R_{i t}\right)$ to assess the orientation of fiscal policy in relation to natural resources $\left(T N R R_{i t}\right)$.

In its implicit form, the state's reaction function in the formulation of fiscal policy can be written as:

$$
\Delta P B_{i t}=P B\left(T N R R_{i t}, \mu_{i t}^{P B}\right)
$$

Or

$$
P B_{i t}=P B\left(T N R R_{i t}, P B_{i t-1}, \mu_{i t}^{P B}\right)
$$

Let the following general specification be used:

$$
P B_{i t}=\alpha_{0}+\alpha_{1} T N R R_{i t}+\alpha_{2} P B_{i t-1}+\mu_{i t}^{P B}
$$


Considering the constraint of public debt sustainability $\left(D E B T_{i t-1}\right)$, to which fiscal policy is subject, as in the works of Wyplosz (2002), Gali and Perotti (2003), Cimadomo (2005), Adedeji and Williams (2007), Equation (3) is written as:

$$
P B_{i t}=\alpha_{0}+\alpha_{1} T_{N R R_{i t}}+\alpha_{2} P B_{i t-1}+\alpha_{3} D E B T_{i t-1}+\mu_{i t}^{P B}
$$

With reference to the work of Alesina and Tabellini (2005), Thornton (2008), Frankel et al. (2013), Calderon \& Nguyen (2016) and Doryñ et al. (2018), institutional quality $\left(Q I_{i t}\right)$ becomes an important variable in explaining the cyclical behavior of fiscal policy. According to the results of this work, a country with strong institutions adopts countercyclical fiscal policies, while a country with weak institutions implements procyclical fiscal policies. Hence, Equation (4) becomes:

$$
P B_{i t}=\alpha_{0}+\alpha_{1} T_{N R R_{i t}}+\alpha_{2} P B_{i t-1}+\alpha_{3} D E B T_{i t-1}+\alpha_{4} Q I_{i t}+\mu_{i t}^{P B}
$$

Based on this theoretical formalization (5), our equation for estimation purposes in its general form links institutional quality and the cyclicality of fiscal policy. This equation is as follows:

$$
\begin{aligned}
P B_{i t}= & \alpha_{0}+\alpha_{1} T_{N R R_{i t}}+\alpha_{2} P B_{i t-1}+\alpha_{3} D E B T_{i t-1}+\alpha_{4} Q I_{i t} \\
& +\alpha_{5} T N R R_{i t} * Q I_{i t}+\alpha_{6} X_{i t}+\varepsilon_{i t}
\end{aligned}
$$

Capturing the behavior of fiscal policy during periods of boom (positive shocks) and collapse (negative shocks) in natural resources, such as in da Costa Antonio and Rodriguez-Gil (2020), leads to dissociating the natural resource cycle in two (Appendix 4). The introduction of periods of boom $\left(P_{-} T N R R_{i t}\right)$ and collapse $\left(N_{-} T N R R_{i t}\right)$ in Equation (6) allows us to rewrite it as:

$$
\begin{aligned}
P B_{i t}= & \beta_{0}+\beta_{1} P \_T N R R_{i t}+\beta_{2} N_{-} T N R R_{i t}+\beta_{3} P B_{i t-1}+\beta_{4} D E B T_{i t-1}+\beta_{5} Q I_{i t} \\
& +\beta_{6} P \_T N R R_{i t} * Q I_{i t}+\beta_{7} N_{-} T N R R_{i t} * Q I_{i t}+\beta_{8} X_{i t}+\varepsilon_{i t}
\end{aligned}
$$

The use of interaction (or multiplicative) terms between the indicators of institutional quality and asymmetric shocks is necessary to assess the role of governance. Specifically, the aim is to assess the role of governance in determining the orientation of fiscal policy during a boom and a collapse in natural resources.

Specifically, based on the examples provided by Doryñ et al. (2018) and Ouedraogo and Souroueemo (2018), our equation for estimation purposes is as follows:

$$
\begin{aligned}
P B_{i t}= & \beta_{0}+\beta_{1} P \_T N R R_{i t}+\beta_{2} N_{-} T N R R_{i t}+\beta_{3} P B_{i t-1}+\beta_{4} D E B T_{i t-1}+\beta_{5} Q I_{i t} \\
& +\beta_{6} P_{-} T N R R_{i t} * Q I_{i t}+\beta_{7} N_{-} T N R R_{i t} * Q I_{i t}+\beta_{8} X_{i t}+\theta_{i}+v_{t}+\mu_{i t}
\end{aligned}
$$

where $\theta_{i}$ is individual effects, making it possible to control for the unobservable and time-invariant characteristics of CEMAC countries whose fiscal policies are potentially correlated; $v_{t}$ is fixed temporal effects, making it possible to control for the time-varying shocks that affect CEMAC countries; $i$ is the individual dimension (of countries); $t$ is the temporal dimension; and $\mu_{i t}$ is the error term, which takes into account the unobserved factors that have an impact on the fiscal policy observed in CEMAC.

$P B_{i t}$ is the budget variable (total public expenditure and total public reve- 
nue); $P B_{i t-1}$ reflects the degree of inertia of fiscal policy due to delays in implementing a new fiscal policy; and $X_{i t}$ is a vector of control variables.

When $\beta_{1}>0$ and significant, it indicates that fiscal policy is procyclical (when $\beta_{1}<0$ and significant, it indicates that fiscal policy is countercyclical). When $\beta_{2}>0$ and significant, it indicates that fiscal policy is countercyclical (when $\beta_{2}<0$ and significant, it indicates that fiscal policy is procyclical). When $\beta_{1}$ and $\beta_{2}$ are not significant, fiscal policy is acyclical.

The importance of $\beta_{1}$ and $\beta_{2}$ indicates the extent of fiscal policy behavior. Additionally, $\beta_{2}$ is assumed to be positive, significant and less than one; it expresses the existence of the long-term balanced budget constraint, which implies a gradual return to equilibrium (stationary variable). When $\beta_{4}$ is positive and significant, it reflects a debt stabilization pattern in the conduct of fiscal policy. When $\beta_{6}>0$ and significant, it indicates that institutional quality amplifies the procyclical nature of fiscal policy (when $\beta_{6}<0$ and significant, it indicates that institutional quality amplifies the countercyclical nature of fiscal policy). When $\beta_{7}>0$ and significant, it indicates that institutional quality amplifies the countercyclical nature of fiscal policy (when $\beta_{7}<0$ and significant, it indicates that institutional quality amplifies the procyclical nature of fiscal policy).

$X_{i t}$ is the vector of control variables that influences fiscal policy independent of the evolution of resource rents. It is composed of: 1) gross domestic product per capita (GDPT), which controls for the differences in the level of development in the actions of the budgetary authorities (see Doryñ et al., 2018); 2) inflation (INFLT), following the example of Guillaumont et al. (2009); its control may be an objective of the monetary authorities, in the same way as regular GDP growth (moreover, a lower inflation rate is one of the quantitative criteria of multilateral surveillance in CEMAC); and 3) net capital inflows, as in Calderon and Schmidt-Hebbel (2008) and Kaminsky et al. (2004); such inflow represent financial constraints. One of the arguments commonly proposed in the literature is that constraints on developing countries' access to international capital markets can lead to procyclical fiscal policies and, consequently, to volatility. The vector of control variables also includes 4) terms of trade. Terms of trade shocks translate into procyclical fiscal policy in the CEMAC region (Mpatswe et al., 2012). Finally, the vector includes 5) trade openness. More open economies reduce the effectiveness of fiscal policy (Karras, 2012).

With regard to estimates, first, it is a matter of estimating the specification without splitting the periods of natural resource boom (positive shocks to natural resources) and collapse (negative shocks to natural resources). Then, we estimate the specification, including the periods of boom and collapse in natural resources.

Additionally, estimating the behavior of fiscal policy, as specified, poses a problem of endogeneity because of the lagged dependent variable, certain unobservable variables and inverse causality. There is a two-way causality between fiscal policy and natural resources. Fluctuations in the natural resource rent of GDP are not independent of fiscal policy. This endogeneity bias is obvious since 
cyclical fiscal policy can create obstacles that will limit export diversification (and thus result in greater dependence on natural resources). In other words, the weakness of public institutions in CEMAC can hamper private sector activities, discourage foreign direct investment and ruin diversification efforts. Under such conditions, resolving this simultaneity bias requires the application of the generalized method of moments (GMM), which provides an efficient estimate (unlike OLS).

The literature on this type of method provides information on two types of estimators: the GMM difference estimator (GMM-Diff) and the GMM system estimator (GMM-Sys). The GMM difference estimator of Arellano and Bond (1991) is based on the first difference of the variables. As a result, it eliminates country-specific effects while taking as instruments appropriate levels of lagged values (in level) for all potentially endogenous variables. This model provides a consistent estimator, especially for sufficiently large $\mathrm{N}$ and relatively small $\mathrm{T}$. One of the limitations of this estimator is the asymptotic weakness of its precision and that of the instruments, leading to considerable biases in finite samples.

Following Arellano and Bover (1995), Blundell and Blond (1998) proposes the GMM system estimator as a solution. This technique deals with the simultaneous estimation of the first-difference equation associated with the level equation. Their model allows the generation of efficient dynamic panel estimators for analyses involving short-period coefficients (where $\mathrm{T}$ is small). The GMM system estimator is much more efficient than the GMM difference estimator.

Additionally, the relevance of this instrumentation method requires ensuring the validity of the Sargan/Hansen overidentification tests and the absence of the autocorrelation of second-order errors. The difference between the Sargan test and the Hansen test is robust to the heteroskedasticity of the error terms.

\section{2) Data sources}

Below, Table 1 describes the analysis variables. The data collected concern the six (06) CEMAC countries. They are annual and cover the 1996-2016 period, i.e., 126 observations. Additionally, all indicators have 2010 as their base year.

Natural resource trend levels are obtained by estimating the Hodrick and Prescott (HP) filter with $\lambda=6.25$ (Ravn and Uhlig, 2002). Doing so makes it possible to calculate the natural resource cycle and, subsequently, to obtain the periods of boom (positive shocks to natural resources) and collapse (negative shocks to natural resources). The choice of the HP filter is justified by its ability to capture the cycles of intermediate frequencies while preserving the length of the series.

Additionally, stationarity tests are not necessary to analyze the characteristics of the series since the time dimension of our panel is less than 24 (Hurlin and Mignon, 2006). The descriptive statistics of the main analysis variables are given in Table 2 below. 
Table 1. Description of the analysis variables.

\begin{tabular}{|c|c|c|c|}
\hline Variable & Description & $\begin{array}{l}\text { Unit of } \\
\text { measure }\end{array}$ & Source \\
\hline gge & Total public expenditure as an indicator of fiscal policy. & $\%$ of GDP & WEO \\
\hline$g g r$ & Total government revenue as an indicator of fiscal policy. & $\%$ of GDP & WEO \\
\hline tnrr & $\begin{array}{l}\text { Total resource rents are revenues from natural resources. } \\
\text { They are measured by the sum of the rents from oil, } \\
\text { natural gas, coal (hard and soft), minerals and forests relative } \\
\text { to gross domestic product. This variable provides information } \\
\text { on an economy's dependence on natural resources. }\end{array}$ & $\%$ of GDP & WDI \\
\hline vacc & $\begin{array}{l}\text { Freedom of expression and accountability. This subindicator } \\
\text { of political governance captures people's perception of their } \\
\text { participation in the choice of elected officials through freedom } \\
\text { of expression, freedom of association and freedom of press. }\end{array}$ & Index & WGI \\
\hline psnv & $\begin{array}{l}\text { Political instability and absence of violence. This subindicator } \\
\text { of political governance measures people's perception of the } \\
\text { likelihood of the destabilization or overthrow of the current } \\
\text { regime by unconstitutional means or violence, } \\
\text { including politically motivated violence and terrorism. }\end{array}$ & Index & WGI \\
\hline gef & $\begin{array}{l}\text { Effectiveness of public action. This subindicator of economic } \\
\text { governance makes it possible to take into account people's } \\
\text { perception of the quality of public services, quality of the } \\
\text { administration and its independence from political pressure, } \\
\text { quality of public policies and credibility of the government's } \\
\text { commitment to these policies. }\end{array}$ & Index & WGI \\
\hline$r q$ & $\begin{array}{l}\text { Quality of regulation. This subindicator of economic } \\
\text { governance captures the population's perception of the } \\
\text { government's ability to formulate and implement policies } \\
\text { and laws that enable the development of the private sector } \\
\text { and the promotion of market laws. }\end{array}$ & Index & WGI \\
\hline$r l$ & $\begin{array}{l}\text { Respect of regulations. This subindicator of institutional } \\
\text { governance captures people's perceptions of agents' trust in } \\
\text { society's laws and the propensity to comply with them. It is } \\
\text { particularly concerned with the quality of contract enforcement, } \\
\text { respect for property rights, the proper functioning of the police } \\
\text { and justice system, and the likelihood of crime and violence. }\end{array}$ & Index & WGI \\
\hline ccorr & $\begin{array}{l}\text { Control of corruption. This subindicator of institutional } \\
\text { governance measures the population's perception of the degree } \\
\text { to which governments seek private gain, including forms of } \\
\text { petty and grand corruption and the confiscation of the state by } \\
\text { elites and private interests. }\end{array}$ & Index & WGI \\
\hline debt & Total public debt. This variable reflects debt sustainability. & $\%$ of GDP & WEO \\
\hline$f d i$ & $\begin{array}{l}\text { Net capital inflows. As a proportion of GDP makes, this variable } \\
\text { makes it possible to assess the role of financing constraints. }\end{array}$ & $\%$ of GDP & WDI \\
\hline ttrad2 & $\begin{array}{l}\text { Terms of the exchange. This variable measures the level of } \\
\text { competitiveness of the economy. }\end{array}$ & & WDI \\
\hline$g d p p c$ & $\begin{array}{l}\text { Real GDP per capita. This variable captures the level of } \\
\text { economic development. }\end{array}$ & $\begin{array}{l}\text { Constant } \\
\text { prices }\end{array}$ & WDI \\
\hline inflt & $\begin{array}{l}\text { Inflation. This variable refers to the rate of price change in the } \\
\text { economy as a whole. }\end{array}$ & $\begin{array}{c}\text { GDP } \\
\text { deflator }(\%)\end{array}$ & WDI \\
\hline trade & $\begin{array}{l}\text { Trade openness. This variable is captured by the share of the } \\
\text { sum of exports and imports of goods and services in gross } \\
\text { domestic product. It provides information on the degree of } \\
\text { openness of the economy. }\end{array}$ & $\%$ of GDP & WDI \\
\hline
\end{tabular}

Source: Authors using actual data from the WEO, WDI and WGI. 
Table 2. Descriptive statistics of the main analysis variables (1996-2016).

\begin{tabular}{|c|c|c|c|c|}
\hline VARIABLE & Average & $\begin{array}{l}\text { Standard } \\
\text { deviation }\end{array}$ & Min & Max \\
\hline \multicolumn{5}{|l|}{ Fiscal Policy Indicators } \\
\hline - Total government spending (gge) & 21.807 & 8.962 & 11.3 & 56.4 \\
\hline - Total government revenues (ggr) & 27.750 & 9.332 & 8.39 & 54.8 \\
\hline Natural Resource Rent (tnrr) & 27.762 & 19.545 & 5.247 & 84.22 \\
\hline \multicolumn{5}{|l|}{ Indicators of Governance } \\
\hline \multicolumn{5}{|l|}{ - Political governance: } \\
\hline$\checkmark$ Freedom of expression and accountability (vacc) & -0.115 & 0.361 & -2 & -0.321 \\
\hline$\checkmark$ Political instability and violence (psnv) & -0.717 & 0.758 & -2.7 & 0.637 \\
\hline \multicolumn{5}{|l|}{ - Economic governance: } \\
\hline$\checkmark \quad$ Effectiveness of public action (gef) & -1.135 & 0.367 & -1.85 & -0.199 \\
\hline$\checkmark \quad$ Quality of regulation (rq) & -0.997 & 0.387 & -1.68 & 0.175 \\
\hline \multicolumn{5}{|l|}{ - Institutional governance: } \\
\hline$\checkmark \quad$ Effective law enforcement ( $\mathbf{r l})$ & -1.165 & 0.359 & -1.84 & -0.206 \\
\hline$\checkmark$ Control of corruption (ccorr) & -1.178 & 0.246 & -1.81 & -0.591 \\
\hline
\end{tabular}

Source: Authors using actual data from the WEO, WDI and WGI.

From Table 1, it can be seen that the fiscal policy variables have means above their standard deviation. These results mean that there is a concentration of fiscal variables around their means. Among CEMAC countries, in the Republic of Congo, both total government expenditure and total government revenue posted the highest levels (56.4 and 54.8) in 2014 and 2008, respectively. Additionally, total public expenditure was at its lowest level (11.3) in Equatorial Guinea (in 2002). Total government revenue, on the other hand, recorded the lowest level in the Central African Republic (in 2013). With respect to natural resource rents, it is apparent that the fiscal policy variables show a concentration of the natural resource rent variable around its average. Over the entire period, Equatorial Guinea (in 2000) recorded the highest natural resource rent (84.22) among CEMAC countries. Similarly, this rent was at the highest level of CEMAC countries in Cameroon (in 1999).

Unlike the budget and natural resources variables, the governance indicators are scattered around their average. Political governance, in terms of freedom of expression and accountability as well as political instability and violence, showed the lowest scores in Equatorial Guinea (in 2015) and the Central African Republic (2014). Over the period, governance posted the highest scores in Gabon (in 1996 and 2000). Additionally, economic governance, in terms of the effectiveness of public action and the quality of regulation, recorded the lowest scores in the Central African Republic (2014) and Equatorial Guinea (2000). These scores were the highest in Gabon (in 1996 and 1998). Institutional governance, based on effective law enforcement and control of corruption, posted the lowest scores in the Central African Republic (2016) and Equatorial Guinea (2016). For this 
type of governance, the highest scores were recorded in Gabon (in 2000 and 2002).

\section{Estimation Results and Discussion}

\section{1) Estimation results}

This section is devoted to the presentation and analysis of the results. It proceeds as follows: a) analysis of the role of institutional quality in the relationship between natural resource rents and the orientation of fiscal policy; and b) analysis of the asymmetrical effects of shocks to natural resource rents.

a) Analysis of the role of institutional quality in the relationship between natural resource rents and the orientation of fiscal policy

Table 3 and Table 4 present the estimation results of the association between dependence on natural resources, institutional quality and fiscal policy in CEMAC. The main diagnostic tests (Hansen, AR (1) and AR (2)) validate the estimation results recorded in Table 3 and Table 4 . The AR (2) statistic attests to the absence of serial correlation of order 2. Hansen's test provides information on the validity of the instruments used in the estimates obtained using generalized method of moments system estimation. In other words, under Hansen's test and AR (2), the null hypothesis is not rejected. Thus, the results obtained are open to interpretation. Additionally, only the estimation results of models 3 and 5 are considered in Table 4 since the Fisher P-values of the other models do not allow for the validity of their overall quality. Subsequently, the period considered (19962016) for the first estimates was subdivided into four (4) subperiods (1996-2000, 2001-2005, 2006-2010 and 2011-2016). In fact, the generalized method of moments (GMM) is more efficient when the periods are short (Bruno, 2005). The estimates made after considering the subperiods led to the same results (reported in Table 3 and Table 4).

From the outset, it is clear that natural resource rents are negatively associated with total public spending. Thus, the coefficient associated with natural resource rents is statistically significant at the $5 \%$ level (for models 3, 4 and 5). With respect to resource rents lagged one period, this result is positively associated with total public expenditure. Similarly, the coefficient for resource rents lagged one period is statistically significant at the $5 \%$ and $10 \%$ levels (for models 3 and 4 , respectively).

The coefficient of the interaction term between the efficiency of public action and natural resource rents is negative and statistically significant at the $10 \%$ level. The coefficient associated with the quality of regulation is positive and statistically significant at the $5 \%$ level. The coefficient of the interaction term between the quality of regulation and natural resource rents is negative and statistically significant at the $10 \%$ level. Similar to the coefficient associated with the quality of regulation, the coefficient associated with the effective application of laws is positive (and statistically significant at the $1 \%$ level). The coefficient of the interaction term between the effective application of laws and natural resource rents is negative and statistically significant at the $10 \%$ level. 
Table 3. The impact of natural resource rents on the orientation of total public spending in CEMAC: the role of institutional quality.

\begin{tabular}{|c|c|c|c|c|c|c|}
\hline & (1) & (2) & (3) & $(4)$ & (5) & (6) \\
\hline Variables & lgge & lgge & lgge & lgge & lgge & lgge \\
\hline \multirow[t]{2}{*}{ L.lgge } & $0.551^{* * *}$ & $0.556^{\star * *}$ & $0.553^{* * *}$ & $0.519^{* * *}$ & $0.508^{\star * *}$ & $0.528^{* * *}$ \\
\hline & $(0.0818)$ & $(0.0850)$ & $(0.0712)$ & $(0.0851)$ & $(0.0828)$ & $(0.0984)$ \\
\hline \multirow[t]{2}{*}{ Tnrr } & -0.00760 & -0.00650 & $-0.0104^{\star *}$ & $-0.00931^{\star *}$ & $-0.00910^{* *}$ & -0.00599 \\
\hline & $(0.00379)$ & $(0.00413)$ & $(0.00381)$ & $(0.00281)$ & $(0.00322)$ & $(0.00389)$ \\
\hline \multirow[t]{2}{*}{ L.tnrr } & 0.0110 & 0.00693 & $0.0160^{* *}$ & $0.00906^{*}$ & 0.00914 & 0.0100 \\
\hline & $(0.00715)$ & $(0.00417)$ & $(0.00548)$ & $(0.00362)$ & $(0.00624)$ & $(0.0101)$ \\
\hline \multirow[t]{2}{*}{ Vacc } & -0.00976 & & & & & \\
\hline & $(0.234)$ & & & & & \\
\hline \multirow[t]{2}{*}{ L.vacc } & 0.0251 & & & & & \\
\hline & $(0.297)$ & & & & & \\
\hline \multirow[t]{2}{*}{ tnr_vac } & -0.00263 & & & & & \\
\hline & $(0.00356)$ & & & & & \\
\hline \multirow[t]{2}{*}{ L.tnr_vac } & 0.00492 & & & & & \\
\hline & $(0.00711)$ & & & & & \\
\hline \multirow[t]{2}{*}{ Psnv } & & 0.163 & & & & \\
\hline & & $(0.126)$ & & & & \\
\hline \multirow[t]{2}{*}{ L.psnv } & & -0.141 & & & & \\
\hline & & $(0.128)$ & & & & \\
\hline \multirow[t]{2}{*}{ tnr_psn } & & -0.00445 & & & & \\
\hline & & $(0.00302)$ & & & & \\
\hline \multirow[t]{2}{*}{ L.tnr_psn } & & 0.00307 & & & & \\
\hline & & $(0.00357)$ & & & & \\
\hline \multirow[t]{2}{*}{ Gef } & & & 0.155 & & & \\
\hline & & & $(0.182)$ & & & \\
\hline \multirow[t]{2}{*}{ L.gef } & & & -0.0678 & & & \\
\hline & & & $(0.164)$ & & & \\
\hline \multirow[t]{2}{*}{ tnr_gef } & & & $-0.00731^{*}$ & & & \\
\hline & & & $(0.00320)$ & & & \\
\hline \multirow[t]{2}{*}{ L.tnr_gef } & & & 0.01000 & & & \\
\hline & & & $(0.00502)$ & & & \\
\hline \multirow[t]{2}{*}{$\mathrm{Rq}$} & & & & $0.583^{* *}$ & & \\
\hline & & & & $(0.147)$ & & \\
\hline \multirow[t]{2}{*}{ L.rq } & & & & -0.340 & & \\
\hline & & & & $(0.184)$ & & \\
\hline
\end{tabular}




\section{Continued}

\begin{tabular}{|c|c|c|c|c|c|c|}
\hline tnr_rq & & & & $\begin{array}{c}-0.00933^{*} \\
(0.00461)\end{array}$ & & \\
\hline L.tnr_rq & & & & $\begin{array}{c}0.00678 \\
(0.00535)\end{array}$ & & \\
\hline $\mathrm{Rl}$ & & & & & $\begin{array}{l}0.341^{\star * *} \\
(0.0796)\end{array}$ & \\
\hline L.rl & & & & & $\begin{array}{l}-0.189 \\
(0.165)\end{array}$ & \\
\hline tnr_rl & & & & & $\begin{array}{l}-0.00686^{*} \\
(0.00315)\end{array}$ & \\
\hline L.tnr_rl & & & & & $\begin{array}{c}0.00513 \\
(0.00480)\end{array}$ & \\
\hline Ccorr & & & & & & $\begin{array}{c}0.135 \\
(0.173)\end{array}$ \\
\hline L.ccorr & & & & & & $\begin{array}{l}-0.194 \\
(0.166)\end{array}$ \\
\hline tnr_ccorr & & & & & & $\begin{array}{r}-0.000941 \\
(0.00644)\end{array}$ \\
\hline L.tnr_ccorr & & & & & & $\begin{array}{c}0.00414 \\
(0.00595)\end{array}$ \\
\hline Ldebt & $\begin{array}{l}0.197^{* * *} \\
(0.0459)\end{array}$ & $\begin{array}{l}0.213^{* *} \\
(0.0648)\end{array}$ & $\begin{array}{l}0.220^{* * *} \\
(0.0428)\end{array}$ & $\begin{array}{l}0.200^{* * *} \\
(0.0446)\end{array}$ & $\begin{array}{l}0.211^{\star * *} \\
(0.0452)\end{array}$ & $\begin{array}{l}0.191^{\star *} \\
(0.0614)\end{array}$ \\
\hline L.ldebt & $\begin{array}{l}-0.230^{\star * *} \\
(0.0558)\end{array}$ & $\begin{array}{l}-0.228^{* *} \\
(0.0597)\end{array}$ & $\begin{array}{l}-0.257^{\star * *} \\
(0.0518)\end{array}$ & $\begin{array}{c}-0.223^{\star * *} \\
(0.0488)\end{array}$ & $\begin{array}{l}-0.229^{* * *} \\
(0.0481)\end{array}$ & $\begin{array}{c}-0.210^{* * *} \\
(0.0491)\end{array}$ \\
\hline Fdi & $\begin{array}{l}-0.00211 \\
(0.00159)\end{array}$ & $\begin{array}{l}-0.00204 \\
(0.00146)\end{array}$ & $\begin{array}{l}-0.00216 \\
(0.00143)\end{array}$ & $\begin{array}{l}-0.00178 \\
(0.00138)\end{array}$ & $\begin{array}{l}-0.00191 \\
(0.00140)\end{array}$ & $\begin{array}{l}-0.00156 \\
(0.00133)\end{array}$ \\
\hline L.fdi & $\begin{array}{c}-0.000635 \\
(0.00181)\end{array}$ & $\begin{array}{c}0.00104 \\
(0.00356)\end{array}$ & $\begin{array}{c}-0.000754 \\
(0.00250)\end{array}$ & $\begin{array}{c}-0.000361 \\
(0.00260)\end{array}$ & $\begin{array}{c}-0.000116 \\
(0.00306)\end{array}$ & $\begin{array}{r}-0.000119 \\
(0.00214)\end{array}$ \\
\hline $\operatorname{ttrad} 2$ & $\begin{array}{l}-0.000 \\
(0.0000)\end{array}$ & $\begin{array}{c}0.000 \\
(0.0000)\end{array}$ & $\begin{array}{l}-0.000 \\
(0.0000)\end{array}$ & $\begin{array}{l}-0.000 \\
(0.0000)\end{array}$ & $\begin{array}{l}-0.000 \\
(0.0000)\end{array}$ & $\begin{array}{l}-0.000 \\
(0.0000)\end{array}$ \\
\hline L.ttrad2 & $\begin{array}{c}0.000 \\
(0.0000)\end{array}$ & $\begin{array}{l}-0.000 \\
(0.0000)\end{array}$ & $\begin{array}{c}0.000 \\
(0.0000)\end{array}$ & $\begin{array}{c}0.000 \\
(0.0000)\end{array}$ & $\begin{array}{c}0.000 \\
(0.0000)\end{array}$ & $\begin{array}{c}0.000 \\
(0.0000)\end{array}$ \\
\hline Lgdppc & $\begin{array}{l}0.366^{*} \\
(0.146)\end{array}$ & $\begin{array}{l}0.329^{*} \\
(0.159)\end{array}$ & $\begin{array}{l}0.330^{*} \\
(0.136)\end{array}$ & $\begin{array}{l}0.245^{\star} \\
(0.102)\end{array}$ & $\begin{array}{c}0.229 \\
(0.209)\end{array}$ & $\begin{array}{c}0.339 \\
(0.197)\end{array}$ \\
\hline L.lgdppc & $\begin{array}{c}-0.362^{* *} \\
(0.141)\end{array}$ & $\begin{array}{l}-0.304 \\
(0.181)\end{array}$ & $\begin{array}{c}-0.353^{\star \star} \\
(0.133)\end{array}$ & $\begin{array}{l}-0.263^{\star *} \\
(0.0989)\end{array}$ & $\begin{array}{l}-0.241 \\
(0.202)\end{array}$ & $\begin{array}{l}-0.322 \\
(0.190)\end{array}$ \\
\hline
\end{tabular}




\section{Continued}

\begin{tabular}{|c|c|c|c|c|c|c|}
\hline \multirow[t]{2}{*}{ Inflt } & -0.000213 & -0.000212 & -0.000213 & -0.000848 & -0.000587 & -0.000140 \\
\hline & $(0.00107)$ & $(0.000805)$ & $(0.00106)$ & $(0.00141)$ & $(0.00120)$ & $(0.000984)$ \\
\hline \multirow[t]{2}{*}{ L.inflt } & 0.000489 & 0.000615 & 0.000384 & 0.00108 & 0.000883 & 0.000497 \\
\hline & $(0.00103)$ & $(0.000921)$ & $(0.00103)$ & $(0.00131)$ & $(0.00114)$ & $(0.000892)$ \\
\hline \multirow[t]{2}{*}{ Trade } & 0.00188 & 0.00205 & 0.00170 & 0.00235 & 0.00140 & 0.00152 \\
\hline & $(0.00142)$ & $(0.00171)$ & $(0.00151)$ & $(0.00159)$ & $(0.00170)$ & $(0.00160)$ \\
\hline \multirow[t]{2}{*}{ L.trade } & 0.00151 & $3.31 \mathrm{e}-05$ & 0.00200 & 0.00146 & 0.00178 & 0.00154 \\
\hline & $(0.000987)$ & $(0.00168)$ & $(0.00116)$ & $(0.00109)$ & $(0.00113)$ & $(0.00117)$ \\
\hline \multirow[t]{2}{*}{ Years } & -0.00280 & -0.00437 & 0.000608 & 0.00385 & -0.00105 & -0.00301 \\
\hline & $(0.00570)$ & $(0.00647)$ & $(0.00462)$ & $(0.00476)$ & $(0.00479)$ & $(0.00478)$ \\
\hline \multirow[t]{2}{*}{ Constant } & 6.768 & 9.759 & 0.168 & -6.208 & 3.602 & 7.059 \\
\hline & (11.45) & (12.85) & $(9.338)$ & $(9.688)$ & $(9.622)$ & $(9.689)$ \\
\hline Obs & 90 & 90 & 90 & 90 & 90 & 90 \\
\hline Number of id & 6 & 6 & 6 & 6 & 6 & 6 \\
\hline $\mathrm{N} \leq \mathrm{i}$ & 90 & 90 & 90 & 90 & 90 & 90 \\
\hline Prob $>$ F & 0.003 & 0.000 & 0.000 & 0.017 & 0.003 & 0.025 \\
\hline $\operatorname{AR}(1)$ & 0.027 & 0.023 & 0.027 & 0.030 & 0.027 & 0.031 \\
\hline $\mathrm{AR}(2)$ & 0.171 & 0.099 & 0.161 & 0.389 & 0.137 & 0.194 \\
\hline Hansen (Prob > Chi2) & 1.000 & 1.000 & 1.000 & 1.000 & 1.000 & 1.000 \\
\hline
\end{tabular}

Robust standard errors in parentheses. ${ }^{* *} p<0.01,{ }^{* *} p<0.05,{ }^{\star} p<0.1$. NB. lgge, logarithm of total government expenditures; L. lgge, logarithm of total government expenditures with a lag period (L.); tnr_vac, interaction term between tnrr and vacc; tnr_psn, interaction term between tnrr and psnv; tnr_gef, interaction term between tnrr and gef; tnr_rq, interaction term between tnrr and rq; tnr_rl, interaction term between tnrr and rl; tnr_ccorr, interaction term between tnrr and ccorr.

Table 4. The impact of natural resource rents on the orientation of total public revenue in CEMAC: the role of institutional quality.

\begin{tabular}{|c|c|c|c|c|c|c|}
\hline & $(1)$ & $(2)$ & (3) & (4) & (5) & $(6)$ \\
\hline Variables & $\operatorname{lggr}$ & $\operatorname{lggr}$ & $\operatorname{lggr}$ & $\operatorname{lggr}$ & lggr & $\operatorname{lggr}$ \\
\hline \multirow[t]{2}{*}{ L.lggr } & 0.160 & 0.175 & 0.235 & 0.154 & 0.192 & 0.1000 \\
\hline & $(0.153)$ & $(0.132)$ & $(0.147)$ & $(0.124)$ & $(0.156)$ & $(0.171)$ \\
\hline \multirow[t]{2}{*}{ Tnrr } & 0.00882 & 0.00943 & $0.0112^{\star}$ & 0.00757 & $0.00782^{*}$ & 0.00381 \\
\hline & $(0.00600)$ & $(0.00562)$ & $(0.00526)$ & $(0.00398)$ & $(0.00337)$ & $(0.00787)$ \\
\hline \multirow[t]{2}{*}{ L.tnrr } & 0.00376 & 0.00193 & 0.00545 & 0.00336 & 0.00664 & $0.0146^{*}$ \\
\hline & $(0.00245)$ & $(0.00424)$ & $(0.00605)$ & $(0.00419)$ & $(0.00372)$ & $(0.00711)$ \\
\hline \multirow[t]{2}{*}{ vacc } & 0.0500 & & & & & \\
\hline & $(0.420)$ & & & & & \\
\hline \multirow[t]{2}{*}{ L.vacc } & 0.0931 & & & & & \\
\hline & $(0.341)$ & & & & & \\
\hline
\end{tabular}




\section{Continued}

\begin{tabular}{|c|c|c|c|c|c|c|}
\hline tnr_vac & $\begin{array}{l}0.000317 \\
(0.00745)\end{array}$ & & & & & \\
\hline L.tnr_vac & $\begin{array}{l}0.000929 \\
(0.00633)\end{array}$ & & & & & \\
\hline psnv & & $\begin{array}{l}0.0808 \\
(0.266)\end{array}$ & & & & \\
\hline L.psnv & & $\begin{array}{l}0.0857 \\
(0.198)\end{array}$ & & & & \\
\hline tnr_psn & & $\begin{array}{l}-0.00259 \\
(0.00750)\end{array}$ & & & & \\
\hline L.tnr_psn & & $\begin{array}{c}-0.000701 \\
(0.00468)\end{array}$ & & & & \\
\hline gef & & & $\begin{array}{l}-0.267 \\
(0.310)\end{array}$ & & & \\
\hline L.gef & & & $\begin{array}{c}0.125 \\
(0.272)\end{array}$ & & & \\
\hline tnr_gef & & & $\begin{array}{l}0.00429 \\
(0.0102)\end{array}$ & & & \\
\hline L.tnr_gef & & & $\begin{array}{c}0.00370 \\
(0.00837)\end{array}$ & & & \\
\hline $\mathrm{rq}$ & & & & $\begin{array}{c}0.113 \\
(0.203)\end{array}$ & & \\
\hline L.rq & & & & $\begin{array}{l}0.0759 \\
(0.153)\end{array}$ & & \\
\hline tnr_rq & & & & $\begin{array}{c}-0.000326 \\
(0.00744)\end{array}$ & & \\
\hline L.tnr_rq & & & & $\begin{array}{c}0.00105 \\
(0.00440)\end{array}$ & & \\
\hline $\mathrm{rl}$ & & & & & $\begin{array}{l}0.491^{\star * *} \\
(0.0980)\end{array}$ & \\
\hline L.rl & & & & & $\begin{array}{c}-0.446^{*} \\
(0.194)\end{array}$ & \\
\hline tnr_rl & & & & & $\begin{array}{l}-0.00446 \\
(0.00564)\end{array}$ & \\
\hline L.tnr_rl & & & & & $\begin{array}{c}0.00744 \\
(0.00510)\end{array}$ & \\
\hline ccorr & & & & & & $\begin{array}{l}0.612^{*} \\
(0.251)\end{array}$ \\
\hline L.ccorr & & & & & & $\begin{array}{r}-0.478^{\star *} \\
(0.179)\end{array}$ \\
\hline
\end{tabular}




\section{Continued}

\begin{tabular}{|c|c|c|c|c|c|c|}
\hline tnr_ccorr & & & & & & -0.00605 \\
\hline & & & & & & $(0.0102)$ \\
\hline L.tnr_ccorr & & & & & & 0.0115 \\
\hline & & & & & & $(0.00656)$ \\
\hline ldebt & -0.0951 & -0.0560 & -0.106 & -0.113 & -0.100 & -0.116 \\
\hline & $(0.209)$ & $(0.174)$ & $(0.212)$ & $(0.205)$ & $(0.198)$ & $(0.207)$ \\
\hline L.ldebt & 0.0840 & 0.0777 & 0.0927 & 0.101 & 0.102 & 0.0969 \\
\hline & $(0.179)$ & $(0.165)$ & $(0.189)$ & $(0.181)$ & $(0.180)$ & $(0.165)$ \\
\hline fdi & -0.00277 & -0.00267 & -0.00255 & -0.00272 & -0.00215 & -0.00191 \\
\hline & $(0.00302)$ & $(0.00211)$ & $(0.00259)$ & $(0.00299)$ & $(0.00209)$ & $(0.00284)$ \\
\hline L.fdi & 0.000353 & 0.00182 & -0.000823 & -0.000109 & $9.97 e-05$ & 0.00100 \\
\hline & $(0.00218)$ & $(0.00391)$ & $(0.00274)$ & $(0.00269)$ & $(0.00309)$ & $(0.00278)$ \\
\hline ttrad2 & $-0.000^{\star}$ & -0.000 & $-0.000^{*}$ & $-0.000^{*}$ & $-0.000^{\star *}$ & $-0.000^{* *}$ \\
\hline & $(0.000)$ & $(0.000)$ & $(0.000)$ & $(0.000)$ & $(0.000)$ & $(0.000)$ \\
\hline L.ttrad2 & 0.000 & 0.000 & 0.000 & 0.000 & 0.000 & 0.000 \\
\hline & $(0.000)$ & $(0.000)$ & $(0.000)$ & $(0.000)$ & $(0.000)$ & $(0.000)$ \\
\hline $\operatorname{lgdppc}$ & 0.882 & 0.940 & $0.957^{\star}$ & 0.869 & 0.739 & $0.915^{\star}$ \\
\hline & $(0.534)$ & $(0.479)$ & $(0.387)$ & $(0.447)$ & $(0.388)$ & $(0.405)$ \\
\hline L.lgdppc & -0.775 & $-0.875^{\star}$ & $-0.860^{*}$ & -0.789 & -0.658 & -0.802 \\
\hline & $(0.529)$ & $(0.412)$ & $(0.386)$ & $(0.444)$ & $(0.385)$ & $(0.410)$ \\
\hline inflt & 0.00151 & 0.00128 & 0.00186 & 0.00170 & 0.000996 & 0.00105 \\
\hline & $(0.00144)$ & $(0.00133)$ & $(0.00135)$ & $(0.00167)$ & $(0.00143)$ & $(0.00142)$ \\
\hline L.inflt & -0.000645 & -0.000537 & -0.000864 & -0.000557 & $-9.29 e-05$ & $-8.37 e-05$ \\
\hline & $(0.00153)$ & $(0.00153)$ & $(0.00149)$ & $(0.00178)$ & $(0.00153)$ & $(0.00143)$ \\
\hline trade & 0.000422 & 0.000291 & 0.000456 & 0.000659 & -0.000342 & -0.000243 \\
\hline & $(0.00156)$ & $(0.00107)$ & $(0.00111)$ & $(0.00121)$ & $(0.000817)$ & $(0.00139)$ \\
\hline L.trade & 0.000162 & -0.000948 & 0.000820 & 0.000594 & 0.000842 & 0.000649 \\
\hline & $(0.00188)$ & $(0.00329)$ & $(0.00178)$ & $(0.00192)$ & $(0.00176)$ & $(0.00126)$ \\
\hline Years & 0.00188 & 0.00137 & -0.00405 & 0.00266 & 0.000461 & 0.00180 \\
\hline & $(0.00530)$ & $(0.00418)$ & $(0.00545)$ & $(0.00501)$ & $(0.00304)$ & $(0.00397)$ \\
\hline Constant & -2.248 & -1.034 & 9.210 & -3.633 & 0.558 & -1.928 \\
\hline & $(10.75)$ & $(8.036)$ & $(11.07)$ & $(10.13)$ & $(6.421)$ & $(8.072)$ \\
\hline Obs & 90 & 90 & 90 & 90 & 90 & 90 \\
\hline Number of id & 6 & 6 & 6 & 6 & 6 & 6 \\
\hline $\mathrm{N} \leq \mathrm{i}$ & 90 & 90 & 90 & 90 & 90 & 90 \\
\hline Prob $>$ F & 0.260 & 0.232 & 0.064 & 0.158 & 0.047 & 0.601 \\
\hline $\operatorname{AR}(1)$ & 0.077 & 0.044 & 0.061 & 0.074 & 0.055 & 0.064 \\
\hline $\mathrm{AR}(2)$ & 0.936 & 0.873 & 0.914 & 0.984 & 0.235 & 0.171 \\
\hline Hansen $($ Prob $>$ Chi2) & 1.000 & 1.000 & 1.000 & 1.000 & 1.000 & 1.000 \\
\hline
\end{tabular}

Robust standard errors in parentheses. ${ }^{* *} p<0.01,{ }^{* *} p<0.05,{ }^{*} p<0.1$. NB. lggr, logarithm of total government revenue. 
The control variables such as period-lagged total government expenditure, total government debt, and real GDP per capita are statistically significant at different levels. This finding suggests that there is no carry-over effect of the control variables on the variables of interest.

The analysis of the results provides information on the fact that natural resource rents can contribute to the orientation of total public spending in CEMAC. It also seems possible that this contribution is possible if economic governance, on the one hand, and institutional governance (including effective law enforcement), on the other hand, are taken into account. It should also be noted that both economic governance and institutional governance contribute to strengthening the countercyclical orientation of total public spending in CEMAC.

Considering only models 3 and 5, it should be noted that natural resource rents are positively and significantly associated with total public revenue at the $10 \%$ level.

The coefficient associated with the quality of regulation is positive and significant at the $1 \%$ level. On the other hand, the coefficient associated with the quality of regulation lagged one period is negative and significant at the $10 \%$ level. Additionally, at least one control variable is statistically significant (i.e., real GDP per capita and terms of trade). Thus, there are no carry-over effects of the control variables on the variables of interest.

Similar to total public spending, natural resource rents can dictate the behavior of total public revenue in CEMAC. Thus, neither economic governance nor institutional governance seems to be a complementary factor in the behavior of total public revenue in CEMAC. It is clear that total public revenue in CEMAC seems to have a procyclical orientation.

b) Analysis of the asymmetrical effects of shocks to natural resource rents

The results found when taking into account the asymmetry of shocks to resource rents are reported in Table 5 and Table 6. Similar to the estimation results found above, the main diagnostic tests for these results are also conclusive.

A positive shock to resource rents is negatively associated with total public spending. This association is statistically significant (except for model 2). A positive shock to resource rents (lagged one period) is positively and significantly associated with total public spending. A negative shock to resource rents is positively associated with total public spending. This association is statistically significant at the 5\% level in model 6. A negative shock to resource rents (lagged one period) is positively and significantly associated with total public spending (except for models 3 and 6).

The coefficient of the interaction term between a positive shock to natural resource rents and freedom of expression and accountability is negatively and significantly associated with total public spending. Additionally, the coefficient of the interaction term between a positive shock to natural resource rents and political instability and violence is negatively and significantly associated with total public spending. The coefficient of the interaction term between a negative shock to natural resource rents and political instability and violence is positively 
Table 5. Asymmetry of the effects of shocks to natural resource rents on the orientation of total public spending in CEMAC: the role of institutional quality.

\begin{tabular}{|c|c|c|c|c|c|c|}
\hline & $(1)$ & (2) & (3) & (4) & (5) & $(6)$ \\
\hline VARIABLES & lgge & lgge & lgge & lgge & lgge & lgge \\
\hline \multirow[t]{2}{*}{ L.lgge } & $0.517^{* * *}$ & $0.582^{* * *}$ & $0.526^{* * *}$ & $0.506^{* * *}$ & $0.499^{* * *}$ & $0.534^{\star * *}$ \\
\hline & $(0.103)$ & $(0.0576)$ & $(0.0909)$ & $(0.0877)$ & $(0.0774)$ & $(0.0904)$ \\
\hline \multirow[t]{2}{*}{ p_tnrr } & $-0.0104^{* * *}$ & -0.00149 & $-0.0123^{\star}$ & $-0.00418^{\star}$ & $-0.00621^{* * *}$ & $-0.0172^{\star * *}$ \\
\hline & $(0.00205)$ & $(0.000894)$ & $(0.00569)$ & $(0.00178)$ & $(0.000712)$ & $(0.00289)$ \\
\hline \multirow[t]{2}{*}{ L.p_tnrr } & -0.000503 & $0.00178^{*}$ & 0.000943 & 0.00125 & 0.00103 & -0.000912 \\
\hline & $(0.00124)$ & $(0.000865)$ & $(0.00513)$ & $(0.00139)$ & $(0.00132)$ & $(0.00339)$ \\
\hline \multirow[t]{2}{*}{ n_tnrr } & 0.00150 & 0.000556 & 0.00235 & -0.00130 & 0.000724 & $0.0145^{\star *}$ \\
\hline & $(0.00532)$ & $(0.00268)$ & $(0.00447)$ & $(0.00134)$ & $(0.00265)$ & $(0.00507)$ \\
\hline \multirow[t]{2}{*}{ L.n_tnrr } & $0.00791^{*}$ & $0.00506^{* * *}$ & 0.00616 & $0.00455^{\star *}$ & $0.00770^{* *}$ & 0.00766 \\
\hline & $(0.00353)$ & $(0.000774)$ & $(0.00337)$ & $(0.00114)$ & $(0.00213)$ & $(0.00550)$ \\
\hline \multirow[t]{2}{*}{ vacc } & 0.0674 & & & & & \\
\hline & $(0.258)$ & & & & & \\
\hline \multirow[t]{2}{*}{ L.vacc } & 0.168 & & & & & \\
\hline & $(0.236)$ & & & & & \\
\hline \multirow[t]{2}{*}{ p_tnrrvacc } & $-0.0112^{\star * *}$ & & & & & \\
\hline & $(0.00260)$ & & & & & \\
\hline \multirow[t]{2}{*}{ L.p_tnrrvacc } & -0.00119 & & & & & \\
\hline & $(0.00248)$ & & & & & \\
\hline \multirow[t]{2}{*}{ n_tnrrvacc } & 0.000978 & & & & & \\
\hline & $(0.00608)$ & & & & & \\
\hline \multirow[t]{2}{*}{ L.n_tnrrvacc } & 0.00563 & & & & & \\
\hline & $(0.00420)$ & & & & & \\
\hline \multirow[t]{2}{*}{ psnv } & & 0.0919 & & & & \\
\hline & & $(0.0810)$ & & & & \\
\hline \multirow[t]{2}{*}{ L.psnv } & & -0.0704 & & & & \\
\hline & & $(0.111)$ & & & & \\
\hline \multirow[t]{2}{*}{ p_tnrrpsnv } & & $-0.00228^{* *}$ & & & & \\
\hline & & $(0.000873)$ & & & & \\
\hline \multirow[t]{2}{*}{ L.p_tnrrpsnv } & & 0.00255 & & & & \\
\hline & & $(0.00191)$ & & & & \\
\hline \multirow[t]{2}{*}{ n_tnrrpsnv } & & 0.000498 & & & & \\
\hline & & $(0.00242)$ & & & & \\
\hline \multirow[t]{2}{*}{ L.n_tnrrpsnv } & & $0.00402^{* * *}$ & & & & \\
\hline & & $(0.000933)$ & & & & \\
\hline
\end{tabular}




\section{Continued}

\begin{tabular}{|c|c|c|c|c|}
\hline \multirow[t]{2}{*}{ gef } & -0.0117 & & & \\
\hline & $(0.164)$ & & & \\
\hline \multirow[t]{2}{*}{ L.gef } & 0.235 & & & \\
\hline & $(0.147)$ & & & \\
\hline \multirow[t]{2}{*}{ p_tnrrgef } & -0.0158 & & & \\
\hline & $(0.00823)$ & & & \\
\hline \multirow[t]{2}{*}{ L.p_tnrrgef } & 0.000164 & & & \\
\hline & $(0.00701)$ & & & \\
\hline \multirow[t]{2}{*}{ n_tnrrgef } & 0.00284 & & & \\
\hline & $(0.00652)$ & & & \\
\hline \multirow[t]{2}{*}{ L.n_tnrrgef } & 0.00441 & & & \\
\hline & $(0.00304)$ & & & \\
\hline \multirow[t]{2}{*}{$\mathrm{rq}$} & & $0.340^{* * *}$ & & \\
\hline & & $(0.0833)$ & & \\
\hline \multirow[t]{2}{*}{ L.rq } & & -0.134 & & \\
\hline & & $(0.104)$ & & \\
\hline \multirow[t]{2}{*}{ p_tnrrrq } & & -0.00682 & & \\
\hline & & $(0.00496)$ & & \\
\hline \multirow[t]{2}{*}{ L.p_tnrrrq } & & 0.00103 & & \\
\hline & & $(0.00356)$ & & \\
\hline \multirow[t]{2}{*}{ n_tnrrrq } & & -0.00354 & & \\
\hline & & $(0.00399)$ & & \\
\hline \multirow[t]{2}{*}{ L.n_tnrrrq } & & $0.00400^{*}$ & & \\
\hline & & $(0.00157)$ & & \\
\hline \multirow[t]{2}{*}{$\mathrm{rl}$} & & \multicolumn{3}{|c|}{$0.243^{\star * *}$} \\
\hline & & \multicolumn{3}{|c|}{$(0.0390)$} \\
\hline \multirow[t]{2}{*}{ L.rl } & & \multicolumn{3}{|c|}{-0.0363} \\
\hline & & \multicolumn{3}{|c|}{$(0.118)$} \\
\hline \multirow[t]{2}{*}{ p_tnrrrl } & & \multicolumn{3}{|c|}{$-0.00664^{\star * *}$} \\
\hline & & \multicolumn{3}{|c|}{$(0.00130)$} \\
\hline \multirow[t]{2}{*}{ L.p_tnrrrl } & & \multicolumn{3}{|c|}{0.000417} \\
\hline & & \multicolumn{3}{|c|}{$(0.00188)$} \\
\hline \multirow[t]{2}{*}{ n_tnrrrl } & & \multicolumn{3}{|c|}{0.000255} \\
\hline & & \multicolumn{3}{|c|}{$(0.00351)$} \\
\hline \multirow[t]{2}{*}{ L.n_tnrrrl } & & & $0.00566^{\star}$ & \\
\hline & & & $(0.00256)$ & \\
\hline ccorr & & & & $0.360^{* *}$ \\
\hline & & & & $(0.0917)$ \\
\hline
\end{tabular}




\section{Continued}

\begin{tabular}{|c|c|c|c|c|c|c|}
\hline L.ccorr & & & & & & $\begin{array}{c}-0.0762 \\
(0.144)\end{array}$ \\
\hline p_tnrrccorr & & & & & & $\begin{array}{c}-0.0163^{* * *} \\
(0.00377)\end{array}$ \\
\hline L.p_tnrrccorr & & & & & & $\begin{array}{l}-0.00114 \\
(0.00361)\end{array}$ \\
\hline n_tnrrccorr & & & & & & $\begin{array}{l}0.0130^{\star *} \\
(0.00380)\end{array}$ \\
\hline L.n_tnrrccorr & & & & & & $\begin{array}{c}0.00399 \\
(0.00550)\end{array}$ \\
\hline ldebt & $\begin{array}{l}0.215^{\star * *} \\
(0.0495)\end{array}$ & $\begin{array}{l}0.261^{* * *} \\
(0.0391)\end{array}$ & $\begin{array}{l}0.235^{\star * *} \\
(0.0485)\end{array}$ & $\begin{array}{l}0.206^{* * *} \\
(0.0393)\end{array}$ & $\begin{array}{l}0.215^{* * *} \\
(0.0494)\end{array}$ & $\begin{array}{l}0.192^{\star *} \\
(0.0663)\end{array}$ \\
\hline L.ldebt & $\begin{array}{l}-0.244^{* *} \\
(0.0710)\end{array}$ & $\begin{array}{l}-0.265^{* * *} \\
(0.0426)\end{array}$ & $\begin{array}{l}-0.248^{\star *} \\
(0.0639)\end{array}$ & $\begin{array}{l}-0.232^{* * *} \\
(0.0478)\end{array}$ & $\begin{array}{l}-0.230^{* *} \\
(0.0615)\end{array}$ & $\begin{array}{l}-0.202^{\star *} \\
(0.0734)\end{array}$ \\
\hline fdi & $\begin{array}{l}-0.00131 \\
(0.00187)\end{array}$ & $\begin{array}{l}-0.00241 \\
(0.00123)\end{array}$ & $\begin{array}{l}-0.00191 \\
(0.00167)\end{array}$ & $\begin{array}{c}-0.000685 \\
(0.00153)\end{array}$ & $\begin{array}{l}-0.00122 \\
(0.00171)\end{array}$ & $\begin{array}{l}-0.00165 \\
(0.00224)\end{array}$ \\
\hline L.fdi & $\begin{array}{c}0.000133 \\
(0.000986)\end{array}$ & $\begin{array}{r}-0.000217 \\
(0.00112)\end{array}$ & $\begin{array}{c}-0.000803 \\
(0.00102)\end{array}$ & $\begin{array}{c}-0.000103 \\
(0.00122)\end{array}$ & $\begin{array}{c}-0.000613 \\
(0.00150)\end{array}$ & $\begin{array}{c}0.000970 \\
(0.000933)\end{array}$ \\
\hline $\operatorname{ttrad} 2$ & $\begin{array}{l}-0.000 \\
(0.000)\end{array}$ & $\begin{array}{c}0.000 \\
(0.000)\end{array}$ & $\begin{array}{l}-0.000 \\
(0.000)\end{array}$ & $\begin{array}{l}-0.000 \\
(0.000)\end{array}$ & $\begin{array}{l}-0.000 \\
(0.000)\end{array}$ & $\begin{array}{l}-0.000 \\
(0.000)\end{array}$ \\
\hline L.ttrad 2 & $\begin{array}{c}0.000 \\
(0.000)\end{array}$ & $\begin{array}{l}-0.000 \\
(0.000)\end{array}$ & $\begin{array}{c}0.000 \\
(0.000)\end{array}$ & $\begin{array}{c}0.000 \\
(0.000)\end{array}$ & $\begin{array}{c}0.000 \\
(0.000)\end{array}$ & $\begin{array}{c}0.000 \\
(0.000)\end{array}$ \\
\hline lgdppc & $\begin{array}{l}0.462^{* * *} \\
(0.101)\end{array}$ & $\begin{array}{l}0.440^{* *} \\
(0.119)\end{array}$ & $\begin{array}{l}0.650^{* *} \\
(0.174)\end{array}$ & $\begin{array}{l}0.372^{\star * *} \\
(0.0905)\end{array}$ & $\begin{array}{l}0.349^{* *} \\
(0.129)\end{array}$ & $\begin{array}{l}0.393 \\
(0.199)\end{array}$ \\
\hline L.lgdppc & $\begin{array}{c}-0.444^{\star * \star} \\
(0.0992)\end{array}$ & $\begin{array}{c}-0.407^{\star *} \\
(0.128)\end{array}$ & $\begin{array}{c}-0.640^{\star *} \\
(0.166)\end{array}$ & $\begin{array}{c}-0.379^{* * *} \\
(0.0914)\end{array}$ & $\begin{array}{c}-0.356^{\star *} \\
(0.130)\end{array}$ & $\begin{array}{l}-0.361 \\
(0.197)\end{array}$ \\
\hline inflt & $\begin{array}{l}-0.000775 \\
(0.000656)\end{array}$ & $\begin{array}{l}-0.000427 \\
(0.000438)\end{array}$ & $\begin{array}{l}-0.000781 \\
(0.000616)\end{array}$ & $\begin{array}{l}-0.000950^{*} \\
(0.000424)\end{array}$ & $\begin{array}{l}-0.000707 \\
(0.000394)\end{array}$ & $\begin{array}{l}-0.000696 \\
(0.000616)\end{array}$ \\
\hline L.inflt & $\begin{array}{c}0.000973 \\
(0.000573)\end{array}$ & $\begin{array}{l}0.000905^{*} \\
(0.000415)\end{array}$ & $\begin{array}{c}0.00105 \\
(0.000609)\end{array}$ & $\begin{array}{l}0.00129^{\star *} \\
(0.000424)\end{array}$ & $\begin{array}{l}0.000980^{* *} \\
(0.000363)\end{array}$ & $\begin{array}{c}0.000984 \\
(0.000510)\end{array}$ \\
\hline trade & $\begin{array}{c}0.00150 \\
(0.00204)\end{array}$ & $\begin{array}{c}0.00243 \\
(0.00173)\end{array}$ & $\begin{array}{c}0.00173 \\
(0.00174)\end{array}$ & $\begin{array}{c}0.00225 \\
(0.00158)\end{array}$ & $\begin{array}{c}0.00150 \\
(0.00155)\end{array}$ & $\begin{array}{c}0.00171 \\
(0.00189)\end{array}$ \\
\hline L.trade & $\begin{array}{c}0.00242 \\
(0.00120)\end{array}$ & $\begin{array}{l}-9.92^{\mathrm{e}}-05 \\
(0.00134)\end{array}$ & $\begin{array}{l}0.00223^{\star} \\
(0.00108)\end{array}$ & $\begin{array}{l}0.00203^{* *} \\
(0.000760)\end{array}$ & $\begin{array}{l}0.00257^{\star *} \\
(0.000874)\end{array}$ & $\begin{array}{c}0.00139 \\
(0.00116)\end{array}$ \\
\hline Years & $\begin{array}{c}-0.000758 \\
(0.00474)\end{array}$ & $\begin{array}{l}-0.00425 \\
(0.00489)\end{array}$ & $\begin{array}{l}0.000955 \\
(0.00422)\end{array}$ & $\begin{array}{c}0.00138 \\
(0.00442)\end{array}$ & $\begin{array}{c}-0.000620 \\
(0.00397)\end{array}$ & $\begin{array}{l}-0.00114 \\
(0.00466)\end{array}$ \\
\hline
\end{tabular}




\section{Continued}

\begin{tabular}{ccccccc}
\hline Constant & 2.892 & 9.353 & -0.617 & -1.296 & 2.764 & 3.576 \\
& $(9.627)$ & $(9.766)$ & $(8.440)$ & $(8.976)$ & $(8.071)$ & $(9.558)$ \\
Obs & 90 & 90 & 90 & 90 & 90 & 90 \\
Number of id & 6 & 6 & 6 & 6 & 6 & 6 \\
N $\leq \mathrm{i}$ & 90 & 90 & 90 & 90 & 90 & 90 \\
Prob > F & 0.060 & 0.001 & 0.004 & 0.009 & 0.009 & 0.014 \\
AR (1) & 0.028 & 0.021 & 0.029 & 0.033 & 0.023 & 0.033 \\
AR (2) & 0.189 & 0.099 & 0.055 & 0.508 & 0.166 & 0.435 \\
Hansen (Prob > Chi2) & 1.000 & 1.000 & 1.000 & 1.000 & 1.000 & 1.000 \\
\hline
\end{tabular}

Robust standard errors in parentheses. ${ }^{* *} p<0.01,{ }^{* *} p<0.05,{ }^{*} p<0.1$. NB. p_tnrrvacc, interaction term

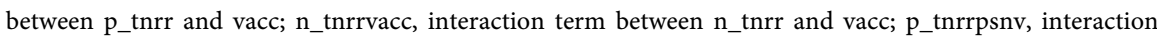
term between p_tnrr and psnv; n_tnrrpsnv, interaction term between n_tnrr and psnv; p_tnrrgef, interaction term between $\mathrm{p} \_$tnrr and gef; $\mathrm{n}$ _tnrrgef, interaction term between $\mathrm{n}$-tnrr and gef; $\mathrm{p} \_$tnrrrq, interaction term between p_tnrr and rq; $n \_t n r r r q$, interaction term between $n \_t n r r$ and rq; $p \_t n r r r l$, interaction term between p_tnrr and rl; n_tnrrrl, interaction term between n_tnrr and rl; p_tnrrccorr, interaction term between p_tnrr and ccorr; $n \_t n r r c c o r r$, interaction term between n_tnrr and ccorr.

Table 6. Asymmetry of the effect of shocks to natural resource rents on the orientation of total public revenue in CEMAC: the role of institutional quality.

\begin{tabular}{|c|c|c|c|c|c|c|}
\hline & (1) & (2) & (3) & (4) & (5) & (6) \\
\hline Variables & $\operatorname{lggr}$ & $\operatorname{lggr}$ & $\operatorname{lggr}$ & $\operatorname{lggr}$ & $\operatorname{lggr}$ & $\operatorname{lggr}$ \\
\hline \multirow[t]{2}{*}{ L.lggr } & 0.257 & 0.297 & 0.343 & 0.238 & 0.267 & 0.190 \\
\hline & $(0.220)$ & $(0.207)$ & $(0.186)$ & $(0.197)$ & $(0.226)$ & $(0.251)$ \\
\hline \multirow[t]{2}{*}{ p_tnrr } & 0.00384 & 0.00223 & 0.00417 & $0.00342^{\star}$ & 0.00471 & -0.00255 \\
\hline & $(0.00333)$ & $(0.00183)$ & $(0.00793)$ & $(0.00145)$ & $(0.00334)$ & $(0.00482)$ \\
\hline \multirow[t]{2}{*}{ L.p_tnrr } & -0.00255 & $1.11 \mathrm{e}-05$ & -0.00463 & -0.00147 & 0.00130 & -0.000725 \\
\hline & $(0.00303)$ & $(0.00300)$ & $(0.00535)$ & $(0.00251)$ & $(0.00278)$ & $(0.00334)$ \\
\hline \multirow[t]{2}{*}{ n_tnrr } & 0.00296 & -0.000212 & 0.000850 & 0.000871 & -0.00232 & 0.0123 \\
\hline & $(0.00641)$ & $(0.00246)$ & $(0.00469)$ & (0.00198) & $(0.00415)$ & $(0.0109)$ \\
\hline \multirow[t]{2}{*}{ L.n_tnrr } & 0.00333 & 0.00261 & 0.00487 & 0.00163 & 0.00131 & $0.0113^{*}$ \\
\hline & $(0.00173)$ & $(0.00219)$ & $(0.00314)$ & $(0.00149)$ & $(0.00454)$ & $(0.00509)$ \\
\hline \multirow[t]{2}{*}{ vacc } & -0.0717 & & & & & \\
\hline & $(0.344)$ & & & & & \\
\hline \multirow[t]{2}{*}{ L.vacc } & 0.213 & & & & & \\
\hline & $(0.352)$ & & & & & \\
\hline \multirow[t]{2}{*}{ p_tnrrvacc } & 0.00246 & & & & & \\
\hline & (0.00509) & & & & & \\
\hline \multirow[t]{2}{*}{ L.p_tnrrvacc } & -0.00223 & & & & & \\
\hline & $(0.00466)$ & & & & & \\
\hline \multirow[t]{2}{*}{ n_tnrrvacc } & 0.000724 & & & & & \\
\hline & $(0.00736)$ & & & & & \\
\hline
\end{tabular}




\section{Continued}

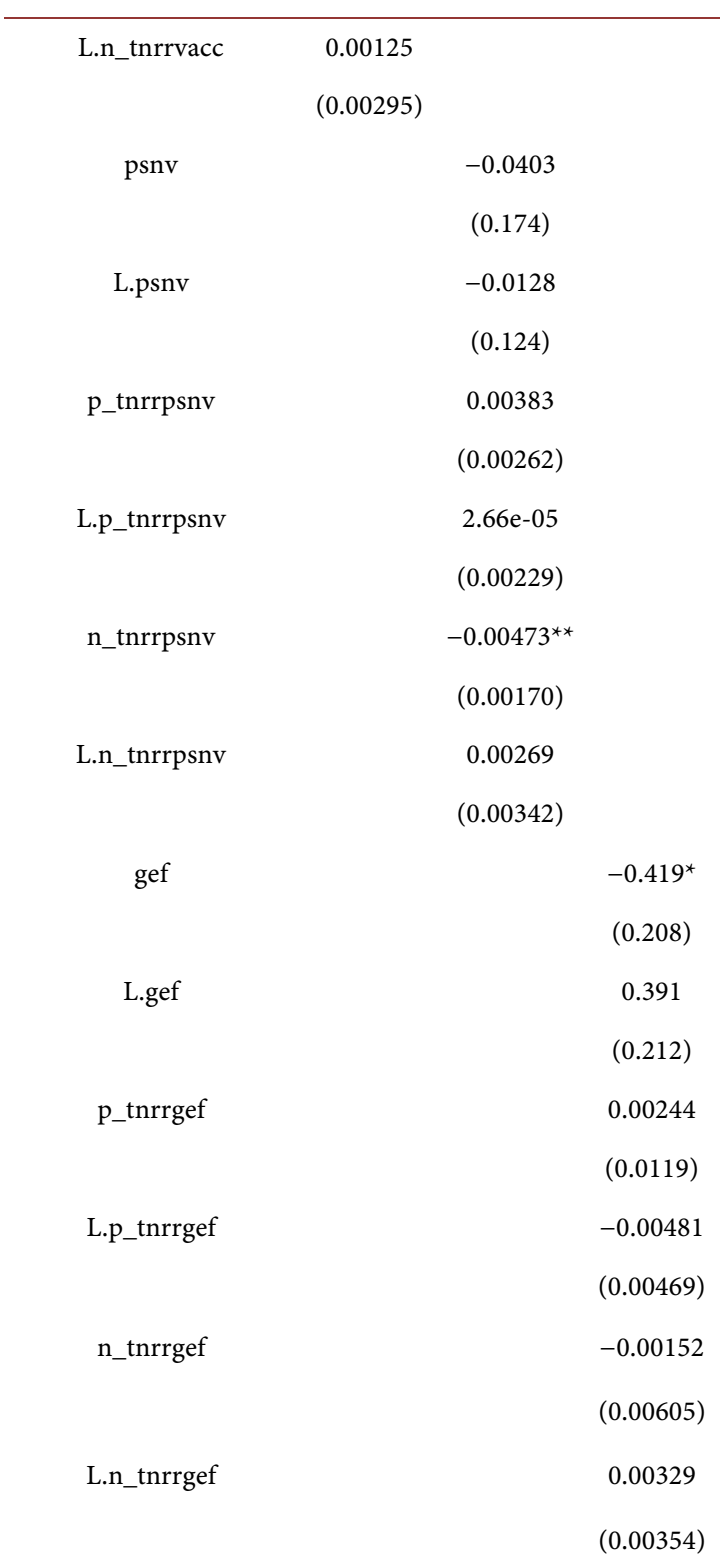

$$
\text { rq }
$$$$
(0.131)
$$$$
\text { L.rq }
$$$$
0.143
$$$$
\text { (0.144) }
$$$$
\text { p_tnrrrq }
$$$$
0.00426
$$$$
\text { (0.00488) }
$$$$
\text { L.p_tnrrrq }
$$$$
-0.000768
$$$$
(0.00521)
$$$$
\text { n_tnrrrq }
$$$$
-0.00288
$$$$
\text { (0.00299) }
$$ 


\section{Continued}

\begin{tabular}{|c|c|c|c|c|c|c|}
\hline L.n_tnrrrq & & & & $\begin{array}{l}-0.00104 \\
(0.00329)\end{array}$ & & \\
\hline $\mathrm{rl}$ & & & & & $\begin{array}{c}0.167 \\
(0.135)\end{array}$ & \\
\hline L.rl & & & & & $\begin{array}{l}-0.153 \\
(0.255)\end{array}$ & \\
\hline p_tnrrrl & & & & & $\begin{array}{c}0.00306 \\
(0.00284)\end{array}$ & \\
\hline L.p_tnrrrl & & & & & $\begin{array}{c}0.00171 \\
(0.00394)\end{array}$ & \\
\hline n_tnrrrl & & & & & $\begin{array}{l}-0.00455 \\
(0.00389)\end{array}$ & \\
\hline L.n_tnrrrl & & & & & $\begin{array}{l}0.000585 \\
(0.00468)\end{array}$ & \\
\hline ccorr & & & & & & $\begin{array}{c}0.359 \\
(0.223)\end{array}$ \\
\hline L.ccorr & & & & & & $\begin{array}{l}0.0567 \\
(0.137)\end{array}$ \\
\hline p_tnrrccorr & & & & & & $\begin{array}{l}-0.00406 \\
(0.00506)\end{array}$ \\
\hline L.p_tnrrccorr & & & & & & $\begin{array}{l}0.000603 \\
(0.00509)\end{array}$ \\
\hline n_tnrrccorr & & & & & & $\begin{array}{l}0.00896 \\
(0.0103)\end{array}$ \\
\hline L.n_tnrrccorr & & & & & & $\begin{array}{c}0.00729 \\
(0.00543)\end{array}$ \\
\hline ldebt & $\begin{array}{l}-0.135 \\
(0.174)\end{array}$ & $\begin{array}{l}-0.133 \\
(0.173)\end{array}$ & $\begin{array}{l}-0.113 \\
(0.165)\end{array}$ & $\begin{array}{l}-0.152 \\
(0.159)\end{array}$ & $\begin{array}{l}-0.139 \\
(0.170)\end{array}$ & $\begin{array}{l}-0.166 \\
(0.161)\end{array}$ \\
\hline L.ldebt & $\begin{array}{c}0.116 \\
(0.166)\end{array}$ & $\begin{array}{c}0.131 \\
(0.167)\end{array}$ & $\begin{array}{l}0.122 \\
(0.164)\end{array}$ & $\begin{array}{l}0.120 \\
(0.160)\end{array}$ & $\begin{array}{c}0.129 \\
(0.167)\end{array}$ & $\begin{array}{c}0.140 \\
(0.156)\end{array}$ \\
\hline fdi & $\begin{array}{l}-0.00220 \\
(0.00341)\end{array}$ & $\begin{array}{c}-0.000811 \\
(0.00185)\end{array}$ & $\begin{array}{l}-0.00151 \\
(0.00234)\end{array}$ & $\begin{array}{l}-0.00206 \\
(0.00280)\end{array}$ & $\begin{array}{l}-0.00159 \\
(0.00282)\end{array}$ & $\begin{array}{l}-0.00213 \\
(0.00340)\end{array}$ \\
\hline L.fdi & $\begin{array}{l}-0.00256 \\
(0.00325)\end{array}$ & $\begin{array}{l}-0.00163 \\
(0.00390)\end{array}$ & $\begin{array}{l}-0.00139 \\
(0.00258)\end{array}$ & $\begin{array}{l}-0.00159 \\
(0.00273)\end{array}$ & $\begin{array}{l}-0.00260 \\
(0.00270)\end{array}$ & $\begin{array}{l}-0.00216 \\
(0.00270)\end{array}$ \\
\hline $\operatorname{ttrad} 2$ & $\begin{array}{l}-0.000 \\
(0.000)\end{array}$ & $\begin{array}{l}-0.000 \\
(0.000)\end{array}$ & $\begin{array}{c}-0.000^{*} \\
(0.000)\end{array}$ & $\begin{array}{c}-0.000^{\star *} \\
(0.000)\end{array}$ & $\begin{array}{l}-0.000 \\
(0.000)\end{array}$ & $\begin{array}{c}-0.000^{\star *} \\
(0.000)\end{array}$ \\
\hline L.ttrad2 & $\begin{array}{c}0.000 \\
(0.000)\end{array}$ & $\begin{array}{c}0.000 \\
(0.000)\end{array}$ & $\begin{array}{l}0.000^{*} \\
(0.000)\end{array}$ & $\begin{array}{c}0.000 \\
(0.000)\end{array}$ & $\begin{array}{c}0.000 \\
(0.000)\end{array}$ & $\begin{array}{c}0.000 \\
(0.000)\end{array}$ \\
\hline
\end{tabular}




\section{Continued}

\begin{tabular}{|c|c|c|c|c|c|c|}
\hline \multirow[t]{2}{*}{$\operatorname{lgdppc}$} & 0.820 & 0.730 & 0.916 & 0.747 & 0.697 & 0.832 \\
\hline & $(0.526)$ & $(0.441)$ & $(0.471)$ & $(0.421)$ & $(0.418)$ & $(0.451)$ \\
\hline \multirow[t]{2}{*}{ L.lgdppc } & -0.719 & -0.614 & -0.804 & -0.677 & -0.612 & -0.721 \\
\hline & $(0.541)$ & $(0.381)$ & $(0.464)$ & $(0.436)$ & $(0.422)$ & $(0.470)$ \\
\hline \multirow[t]{2}{*}{ inflt } & $0.00246^{* *}$ & $0.00255^{\star *}$ & $0.00250^{* *}$ & $0.00263^{* *}$ & $0.00244^{* *}$ & $0.00225^{\star}$ \\
\hline & $(0.000932)$ & $(0.000853)$ & $(0.000887)$ & $(0.001000)$ & $(0.000896)$ & $(0.000938)$ \\
\hline \multirow[t]{2}{*}{ L.inflt } & -0.00152 & -0.00157 & -0.00150 & -0.00148 & -0.00144 & -0.00121 \\
\hline & $(0.00109)$ & $(0.000921)$ & $(0.000991)$ & $(0.00108)$ & $(0.000976)$ & $(0.00103)$ \\
\hline \multirow[t]{2}{*}{ trade } & 0.00188 & 0.00218 & 0.000523 & 0.00194 & 0.00119 & 0.00168 \\
\hline & $(0.00241)$ & $(0.00163)$ & $(0.00144)$ & $(0.00165)$ & $(0.00160)$ & $(0.00211)$ \\
\hline \multirow[t]{2}{*}{ L.trade } & 0.00227 & 0.000788 & 0.00189 & 0.00263 & 0.00257 & $0.00267^{* *}$ \\
\hline & $(0.00181)$ & $(0.00243)$ & $(0.00167)$ & $(0.00133)$ & $(0.00162)$ & $(0.000896)$ \\
\hline \multirow[t]{2}{*}{ Years } & -0.00244 & -0.00601 & $-0.00731^{\star}$ & -0.00211 & -0.00449 & -0.00263 \\
\hline & $(0.00552)$ & $(0.00656)$ & $(0.00312)$ & $(0.00489)$ & $(0.00457)$ & $(0.00471)$ \\
\hline \multirow[t]{2}{*}{ Constant } & 6.198 & 12.93 & $15.44^{*}$ & 5.816 & 10.23 & 7.038 \\
\hline & (11.16) & $(13.25)$ & $(6.434)$ & $(9.882)$ & $(9.669)$ & $(9.414)$ \\
\hline Obs & 90 & 90 & 90 & 90 & 90 & 90 \\
\hline Number of id & 6 & 6 & 6 & 6 & 6 & 6 \\
\hline $\mathrm{N} \leq \mathrm{i}$ & 90 & 90 & 90 & 90 & 90 & 90 \\
\hline Prob $>$ F & 0.050 & 0.001 & 0.004 & 0.009 & 0.009 & 0.014 \\
\hline $\operatorname{AR}(1)$ & 0.028 & 0.021 & 0.029 & 0.033 & 0.023 & 0.033 \\
\hline AR (2) & 0.189 & 0.099 & 0.055 & 0.508 & 0.166 & 0.435 \\
\hline Hansen (Prob > Chi2) & 1.000 & 1.000 & 1.000 & 1.000 & 1.000 & 1.000 \\
\hline
\end{tabular}

Robust standard errors in parentheses. ${ }^{* *} p<0.01,{ }^{* *} p<0.05,{ }^{*} p<0.1$.

and significantly associated with total public expenditure at the 5\% level. Similarly, the coefficient on the quality of regulation is positively and significantly associated with total public spending.

The coefficient of the interaction term between a negative shock to natural resource rents (lagged one period) and the quality of regulation is positively and significantly associated with total public spending at the $10 \%$ level. The coefficient of the effective application of laws is positively and significantly associated with total public expenditure at the $1 \%$ level. The coefficient of the interaction term between a positive shock to natural resource rents and effective law enforcement is negatively and significantly associated with total public expenditure at the $1 \%$ level. On the other hand, the coefficient of the interaction term between a negative shock to resource rents (lagged one period) and effective enforcement is positively and significantly associated with total public spending at the $10 \%$ level. 
The corruption control coefficient is positively and significantly associated with total public spending at the $5 \%$ level. The coefficient of the interaction term between a positive shock to natural resource rents and corruption control is negatively and significantly associated with total public expenditure at the $1 \%$ level. On the other hand, a negative shock to natural resource rents and control of corruption is positively and significantly associated with total public expenditure at the $5 \%$ level.

Each model estimated finds that at least one control variable is significantly associated with total government spending. As a result, there are no carry-over effects of the control variables on the variables of interest.

A positive shock to natural resource rents is likely to induce a countercyclical orientation of total public spending in CEMAC. Political and institutional governance contributes to strengthening the effects of the increase in natural resource rents on the countercyclical orientation of total public spending in CEMAC. Furthermore, a negative shock to natural resource rents can dictate the countercyclical behavior of total public spending in CEMAC. Additionally, institutional governance (through the control of corruption) can contribute to reinforcing the effects of a decline in natural resource rents on the countercyclical orientation of total public spending in CEMAC.

A positive shock to natural resource rents is positively and significantly associated with total public revenue at the $10 \%$ level. In turn, a negative shock to natural resource rents is negatively and significantly associated with total public revenue at the $5 \%$ level. The coefficient of policy effectiveness is negatively and significantly associated with total public revenue at the $10 \%$ level. The coefficient of the interaction term between a negative shock to natural resource rents and political instability and violence is negatively and significantly associated with total public revenue at the $5 \%$ level. In addition, at least one control variable is significantly associated with total public revenue. Thus, there are no carry-over effects of the control variables on the variables of interest.

In CEMAC, the quality of political governance (in terms of political instability and violence) can complement negative shocks to natural resource rents in guiding the procyclical behavior of total public revenue. Thus, regardless of the shocks, total public revenue remains procyclical.

\section{2) Discussion}

The analysis of the results allows us to draw the following lesson: institutional quality, which is a factor with mixed effects on natural resource rents, plays a role in the orientation of fiscal policy. This main lesson can be divided into two. a) Regarding political, economic and institutional governance, these factors, which have complementary effects on natural resource rents, play a role in the countercyclical orientation of total public spending. b) Regarding political governance, which is a factor with complementary effects on the decline in natural resource rents, plays a role in the procyclical orientation of total public revenue.

a) Political, economic and institutional governance: factors that have complementary effects on natural resource rents and that play a role in the counter- 
cyclical orientation of total public spending

Dependence on natural resources conditions a countercyclical orientation of total public spending in CEMAC. This countercyclical behavior of public spending may be due to the consideration of governance.

In fact, economic and institutional governance (the effective enforcement of laws) in CEMAC complements the role played by natural resource rents in the countercyclical orientation of total public spending. Thus, regardless of whether there are periods of boom or collapse in natural resource rents, total public spending remains countercyclical. Therefore, political and institutional governance contributes to reinforcing the boom effects of natural resource rents on the countercyclical orientation of total public spending. For its part, institutional governance contributes to reinforcing the effects of a collapse in natural resource rents on the countercyclical orientation of total public spending. In line with El Anshasy and Bradley (2012), Koh (2017) and da Costa Antonio and RodriguezGil (2020), the results suggest that improving the quality of institutions in resource-rich countries corrects the procyclical bias of fiscal policy.

The reforms undertaken to improve the quality of governance in CEMAC have contributed to improved performance in economic, political and institutional governance. This improvement in institutional quality, particularly economic, political and institutional governance, is reflected in improved transparency, responsibility and accountability in political decision-making (Acemoglu and Robinson, 2010). Thus, improving institutional quality is associated with less information asymmetry and, as a result, makes the conduct of fiscal policy more transparent, more deliberate and, therefore, less wasteful.

In the same vein, in CEMAC, reforms to strengthen transparency and public financial management have been launched and accelerated through the adoption of the new Finance Law (LOF). Consequently, through the channel of natural resource rents, improving institutional quality dictates a countercyclical behavior of total public spending.

b) Political governance: a factor that has complementary effects on the decline in natural resource rents and that plays a role in the procyclical orientation of total government revenue

In terms of total government revenue, dependence on natural resources dictates a procyclical orientation. This result is in line with the work of Antonio and Rodriguez-Gil (2020). According to these authors, natural resources, especially oil, condition the procyclical behavior of public revenues in Angola.

For Spatafora and Samake (2012), dependence on natural resources complicates the management of fiscal policy and debt, which encourages a procyclical fiscal policy and threatens debt sustainability. Similarly, this procyclical behavior of total government revenue remains the same, regardless of whether there are periods of boom or collapse in natural resource rents.

For its part, political governance (in terms of political instability and violence) reinforces the effects of a negative shock to natural resource rents on the orien- 
tation of the procyclical behavior of total public revenue.

At present, governance performance does not allow the procyclical bias of fiscal policy to be corrected by total government revenue. According to the IMF (2013), institutions in Central Africa are efficient in managing natural resources, particularly oil. Thus, the limited room for maneuvering in fiscal policy due to the concentration of exports in CEMAC is likely to condition a procyclical behavior of total public revenue (Ouedraogo and Souroueemo, 2018).

\section{Conclusion and Policy Implications}

The objective of this paper was to analyze the effects of institutional quality through natural resource rents on the orientation of fiscal policy in CEMAC. Asymmetric shocks to natural resource rents were then considered. This research expands the scarce literature on the asymmetry of fiscal policy and helps to shed light on the still ambiguous role of institutions in resource-rich economies. The methodology adopted for this purpose is based on panel data (over the 1996-2016 period) and the GMM system estimator.

Our results indicate that, on the one hand, total public spending is countercyclical with respect to natural resources. Additionally, this behavior may be rooted in improved institutional quality (political, economic and institutional governance). Consequently, through the channel of natural resource rents, improved institutional quality amplifies the countercyclical behavior of total public spending. Thus, regardless of whether there are periods of boom or collapse in natural resource rents, the results remain unchanged.

On the other hand, total government revenues are procyclical with respect to natural resources rents, regardless of whether there are periods of boom or collapse. Moreover, political governance (in terms of political instability and violence) reinforces the effects of a negative shock to natural resource rents on the orientation of the procyclical behavior of total public revenue.

In terms of implications, the quality of governance in CEMAC needs to be improved to better contribute to the countercyclicality of public spending. This behavior contributes to economic stabilization and, thus, to sustained growth. It will also be necessary to improve the governance of natural resources and to encourage export diversification. For future research, we plan to investigate determinants of the procyclicality of fiscal policy by focusing on three types of public spending: total public spending, public consumption spending and public investment spending.

\section{Conflicts of Interest}

The authors declare no conflicts of interest regarding the publication of this paper.

\section{References}

Acemoglu, D., \& Robinson, J. (2010). The Role of Institutions in Growth and Develop- 
ment. Review of Economics and Institutions, 1. https://doi.org/10.5202/rei.v1i2.14

Adedeji, O., \& Williams, O. H. (2007). Fiscal Reaction Functions in the CFA Zone: An Analytical Perspective. IMF Working Papers 07/232, International Monetary Fund, 21 p. https://doi.org/10.5089/9781451867961.001

Aizenman, J., Gavin, M., \& Hausmann, R. (2000). Optimal Tax and Debt Policy with Endogenously Imperfect Creditworthiness. Journal of International Trade \& Economic Development, 9, 367-395. https://doi.org/10.1080/096381900750056830

Alesina, A., Campante, F. R., \& Tabellini, G. (2008). Why Is Fiscal Policy Often Pro-Cyclical? Journal of the European Association, 6, 1006-1036. https://doi.org/10.1162/JEEA.2008.6.5.1006

Alesina, A., \& Tabellini, G. (2005). Why Is Fiscal Policy Often Procyclical? NBER Working Paper n_11600. https://doi.org/10.3386/w11600

Arellano, M., \& Bond, S. (1991). Some Test of Specification for Panel Data: Monte Carlo Evidence and an Application to Employment Equations. Review of Economic Studies, 58, 277-297. https://doi.org/10.2307/2297968

Arellano, M., \& Bover, O. (1995). Another Look at the Instrumental Variable Estimation of Error-Components Models. Journal of Econometrics, 68, 29-51. https://doi.org/10.1016/0304-4076(94)01642-D

Bergman, U. M., \& Hutchison, M. (2020). Fiscal Procyclicality in Emerging Markets: The Role of Institutions and Economic Conditions. International Finance, 23, 196-214. https://doi.org/10.1111/infi.12375

Blundell, R., \& Bond, S. (1998). Initial Conditions and Moment Restrictions in Dynamic Panel Data Models. Journal of Econometrics, 87, 115-143. https://doi.org/10.1016/S0304-4076(98)00009-8

Bouanza, K. J. R. F., Ngassa, T. C., \& Ndinga, M. M. A. (2018). The Effects of Regulatory Quality on the Pro-Cyclicality of Fiscal Policy in Countries in the Central African Economic and Monetary Community (CA EMC). Modern Economy, 9, 1228-1246. https://doi.org/10.4236/me.2018.97080

Bova, E., Medas, P., \& Poghosyan, T. (2016). Macroeconomic Stability in CommodityRich Countries: The Role of Fiscal Policy. IMF Working Paper WP/16/36. https://doi.org/10.5089/9781475596465.001

Bruno, G. S. (2005). Estimation and Inference in Dynamic Unbalanced Panel-Data Models with a Small Number of Individuals. STATA Journal, 5, 473-500. https://doi.org/10.1177/1536867X0500500401

Calderon, C., \& Nguyen, H. (2016). The Cyclical Nature of Fiscal Policy in Sub-Saharan Africa. Journal of African Economies, 25, 548-579. https://doi.org/10.1093/jae/ejw007

Calderon, C., \& Schmidt-Hebbel, K. (2008). Business Cycles and Fiscal Policies: The Role of Institutions and Financial Markets. Central Bank of Chile Working Papers $N_{-} 481$.

Cespedes, L. F., \& Velasco, A. (2014). Was This Time Different? Fiscal Policy in Commodity Republics. Journal of Development Economics, 106, 92-106. https://doi.org/10.1016/j.jdeveco.2013.07.012

Cimadomo, J. (2005). Le pacte de stabilité a-t-il renforce la pro cyclicité de la politique budgétaire (4 p.). La lettre du CEPII (Centre d'Etudes Prospectives et d'Informations Internationales), No. 247.

da Costa Antonio, A. E., \& Rodriguez-Gil, A. (2020). Oil Shocks and Fiscal Policy Procyclicality in Angola: Assessing the Role of Asymmetries and Institutions. Review of Development Economics, 24, 209-237. https://doi.org/10.1111/rode.12633 
Doryñ, W., Mackiewicz, M., \& Wawrzyniak, D. (2018). The Role of Institutions in Determining the Cyclical Behavior of Fiscal Policy (28 p.). Lodz Economics, Working Papers No. $2 / 2018$.

El Anshasy, A., \& Bradley, M. D. (2012). Oil Prices and the Fiscal Policy Response in Oil-Exporting Countries. Journal of Policy Modeling, 34, 605-620. https://doi.org/10.1016/j.jpolmod.2011.08.021

Frankel, J. A., Vegh, C. A., \& Vuletin, G. (2013). On Graduation from Fiscal Procyclicality. Journal of Development Economics, 100, 32-47. https://doi.org/10.1016/j.jdeveco.2012.07.001

Gali, J., \& Perrotti, R. (2003). Fiscal Policy and Monetary Integration in Europe (45 p.). NBER Working Paper, No. 9773. https://doi.org/10.3386/w9773

Gavin, M., Hausmann, R., Perotti, R., \& Talvi, E. (1996). Managing Fiscal Policy in Latin America and the Caribbean: Volatility, Procyclicality, and Limit Creditworthiness. IADB Office of the Chief Economist Working Paper 326. https://doi.org/10.2139/ssrn.1815955

Gavin, M., \& Perotti, R. (1997). Fiscal Policy in Latin America. In B. Bernanke, \& J. Rotemberg (Eds.), NBER Macroeconomics Annual 1997 (pp. 11-61). Cambridge, MA and London: MIT Press. https://doi.org/10.1086/654320

Guillaumont, J., Tapsoba, S., \& Sylviane (2009). Pro cyclicité de la politique budgétaire et surveillance multilatérale dans les unions monétaires africaines. Working Papers No. 200904 from CERDI, $49 \mathrm{p}$.

Ilzetski, E., \& Vegh, C. A. (2008). Procyclical Fiscal Policy in Developing Countries: Truth or Fiction? NBER Working Paper 14191. https://doi.org/10.3386/w14191

Jha, S., Mallick, S. K., Park, Park, D., \& Quising, P. F. (2014). Effectiveness of Countercyclical Fiscal Policy: Evidence from Developing Asia. Journal of Macroeconomics, 40, 82-98. https://doi.org/10.1016/j.jmacro.2014.02.006

Kaminsky, G., Reinhart, C., \& Vegh, C. A. (2004). When It Rains It Pours: Procyclical Capital Flows and Macroeconomic Policies. NBER Working Papers 10780. National Bureau of Economic Research, Inc.

Karras, G. (2012). Trade Openness and the Effectiveness of Fiscal Policy: Some Empirical Evidence. International Review of Economics, 59, 303-313. https://doi.org/10.1007/s12232-011-0126-9

Kaufmann, D., Kraay, A., \& Mastruzzi, M. (2010). The Worldwide Governance Indicators: Methodology and Analytical Issues (September 2010) (31 p.). World Bank Policy Research Working Paper, No. 5430.

Koh, W. C. (2017). Fiscal Policy in Oil-Exporting Countries: The Roles of Oil Funds and Institutional Quality. Review of Development Economics, 21, 567-590. https://doi.org/10.1111/rode.12293

Konuki, T., \& Villafuerte, M. (2016). Cyclical Behavior of Fiscal Policy among Sub-Saharan African Countries. Washington DC: International Monetary Fund.

Lane, P. (2003). The Cyclical Behavior of Fiscal Policy: Evidence from the OECD. Journal of Public Economics, 87, 1661-1675. https://doi.org/10.1016/S0047-2727(02)00075-0

Lane, P. R., \& Tornell, A. (1999). The Voracity Effect. American Economic Review, 89, 22-46. https://doi.org/10.1257/aer.89.1.22

Lim, J. J. (2020). The Political Economy of Fiscal Procyclicality. European Journal of Political Economy, 65, 196-214. https://doi.org/10.1016/j.ejpoleco.2020.101930

Lledó, V., \& Poplawski-Ribeiro, M. (2013). Fiscal Policy Implementation in Sub-Saharan 
Africa. World Development, 46, 79-91. https://doi.org/10.1016/j.worlddev.2013.01.030

Lledo, V., Yackovlev, I., \& Gadenne, L. (2009). Cyclical Patterns of Government Expenditures in Sub-Saharan Africa: Facts and Factors. IMF Working Paper 09/274, Washington DC: International Monetary Fund. https://doi.org/10.5089/9781451874198.001

Mpatswe, J., Tapsoba, S.-A., \& York, R. (2012). The Cyclicality of Fiscal Policies in the CEMAC Region. In Oil Wealth in Central Africa: Policies for Inclusive Growth. Washington DC: International Monetary Fund.

Ndinga, M. M. A. (2018). La gouvernance dans les pays africains au sud du Sahara: Quelles incidences sur l'emploi? Publié dans Gouvernance et performance: Une perspective internationale, sous la direction de: Félix Zogning et Muriel Dufour. éd. JFD.

Ouedraogo, R., \& Sourouema, W. S. (2018). Fiscal Policy Pro-Cyclicality in Sub-Saharan African Countries: The Role of Export Concentration. Economic Modelling, 74, 219-229. https://doi.org/10.1016/j.econmod.2018.05.017

Ravn, M. O., \& Uhlig, H. (2002). On Adjusting the Hodrick-Prescott Filter for the Frequency of Observations. Review of Economics and Statistics, 84, 371-376. https://doi.org/10.1162/003465302317411604

Schaechter, A., Kinda, T., Budina, N., \& Weber, A. (2012). Fiscal Rules in Response to the Crisis toward the "Next-Generation" Rules. A New Dataset. IMF Working Paper \#187.

Spatafora, N., \& Samake, I. (2012). Commodity Price Shocks and Fiscal Outcomes. Washington DC: International Monetary Fund, Research Department and Western Hemisphere Department, IMF Working Paper WP/12/112. https://doi.org/10.5089/9781475503333.001

Talvi, E., \& Vegh, C. A. (2005). Tax Base Variability and Procyclical Fiscal Policy in Developing Countries. Journal of Development Economics, 78, 156-190. https://doi.org/10.1016/j.jdeveco.2004.07.002

Taylor, J. B. (2000). Reassessing Discretionary Fiscal Policy. Journal of Economic Perspectives, 14, 21-36. https://doi.org/10.1257/jep.14.3.21

Thornton, J. (2008). Explaining Procyclical Fiscal Policy in African Countries. Journal of African Economies, 17, 451-464. https://doi.org/10.1093/jae/ejm029

WDI (2018). World Development Indicators. https://www.wdi.worldbank.org

WEO (2018). World Economic Outlook-Database-International Monetary Fund (FMI). https://www.imf.org/en/Publications/WEO/weo-database/2018/October

WGI (2018). The Worldwide Governance Indicator, 1996-2017. http://info.worldbank.org/governance/wgi/pdf/EIU.xlsx

Wyplosz, C. (2002). Fiscal Policy: Institutions versus Rules (40 p.). CEPR Discussion Papers 3238, CEPR Discussion Papers.

Zhou, Y. (2009). International Reserves and Fiscal Policy in Developing Countries. Review of International Economics, 17, 942-960. https://doi.org/10.1111/j.1467-9396.2008.00803.x

Zhou, Y. (2010). The Underlying Link between Fiscal Policy Patterns and International Reserves. Review of Development Economics, 14, 712-725. https://doi.org/10.1111/j.1467-9361.2010.00583.x 
Appendix 1. List of Countries Belonging to the Economic and Monetary Community of Central African States (CEMAC)

\begin{tabular}{cccccc}
\hline No. & Country & Code & No. & Country & Code \\
\hline 1 & Central African Republic & CAF & 4 & Gabon & GAB \\
2 & Cameroon & CMR & 5 & Equatorial Guinea & GNQ \\
3 & Congo & COG & 6 & Chad & TCD \\
\hline
\end{tabular}

Source: Authors based on the countries in the WDI database.

\section{Appendix 2. Correlations between Natural Resource Rents and Fiscal Policy in CEMAC}

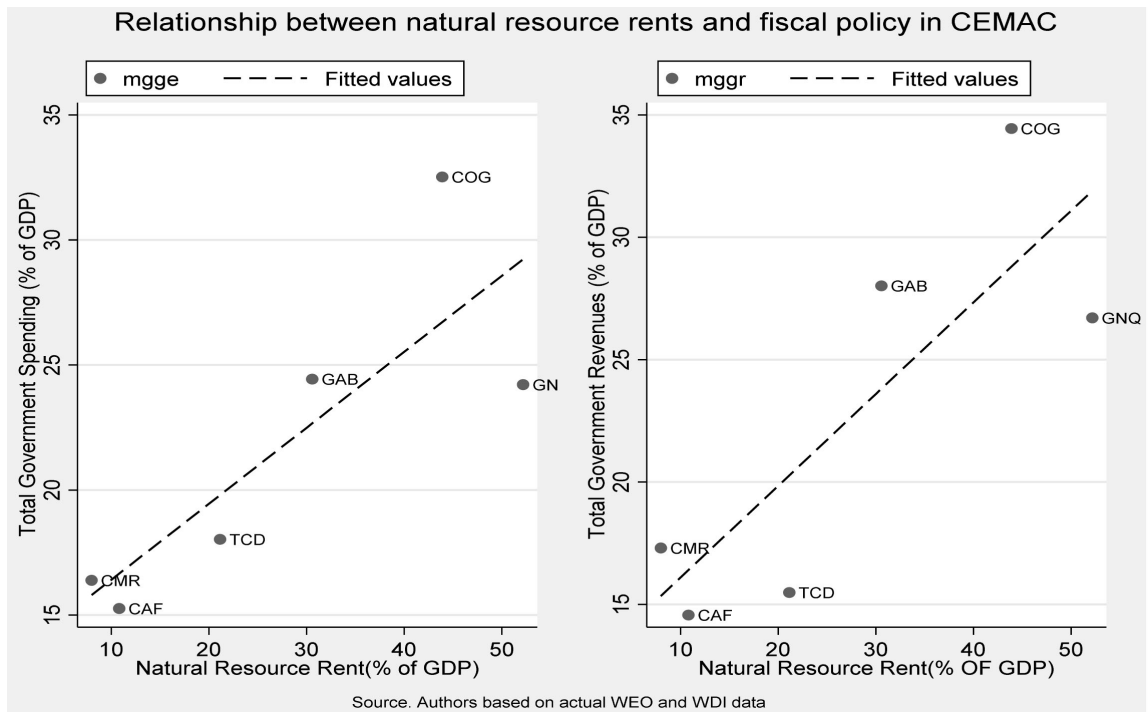

\section{Appendix 3. Trends in Governance Indicators in CEMAC}

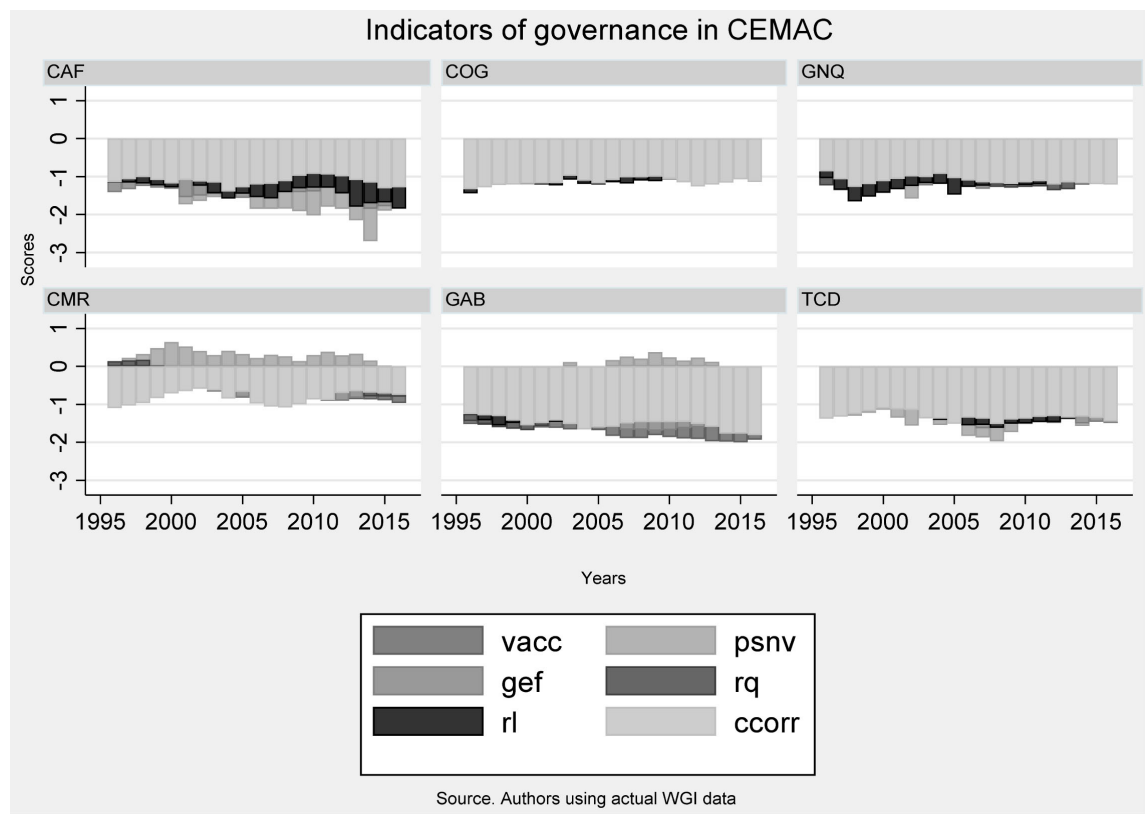


Appendix 4. Calculation of Periods of Boom and Collapse in Natural Resource Rents

\begin{tabular}{|c|c|}
\hline Variable & \\
\hline & Indicators of the phases of the business cycle \\
\hline \multirow{3}{*}{$P \_T N R R_{i t}$} & Boom period (calculation made by the authors using this formula): \\
\hline & $P_{-} T N R R_{i t}=T \dot{N} R R_{i t} * T \dot{N} R R_{i t}(>0)$ \\
\hline & 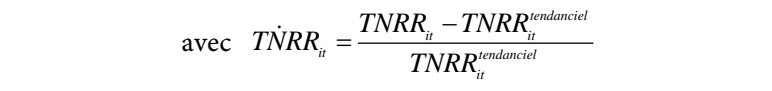 \\
\hline$N_{-} T_{N R R_{i t}}$ & $\begin{array}{l}\text { Collapse period (calculation by the authors based on this formula): } \\
\left.\qquad N_{-} T N R R_{i t}=T \dot{N} R R_{i t} * T \dot{N} R R_{i t}(<0)\right)\end{array}$ \\
\hline
\end{tabular}

Source: Authors using WDI data. 